\title{
The effect of moisture on the properties of cement-bonded particleboards made with non-traditional raw materials
}

\author{
Tomas Melichar ${ }^{*}$ ( , Lenka Meszarosova, Jiri Bydzovsky, Matej Ledl and Silvestr Vasas
}

\begin{abstract}
The paper presents research into the changes of properties in cement-bonded particleboards caused by moisture saturation over the course of $504 \mathrm{~h}$. Three particleboard variants were tested, all at the age of 18 months. The first is a standard production-line board manufactured by CIDEM Hranice, a.s. (identified as CP-R). The other two variants were modified by by-products of the particleboard manufacturing process-dust (CP-D) and a particulate mixture (CP-P). The experiment observed changes in the boards' dimensions, volume, and mass. The effect of moisture on their basic material properties was also investigated. While the boards were being saturated by water, changes in their structure were examined using an optical microscope. It was found that the boards behave differently depending on their composition. Also there were differences in the dynamics of the property changes. The modified particleboards are more susceptible to dimensional and volume changes. Both, volume and mass undergo the most significant changes during the first $24 \mathrm{~h}$. Cracks and air voids inside the wood chips begin to close upon contact with water as a result of swelling. It was observed by optical microscopy that this process occurs within 3 to 5 min since immersion in the water bath. Between 24 and $96 \mathrm{~h}$ the rate at which the air voids and pores are closing begins to decrease and there is a difference in the dynamics of mass and volume changes as well. Wet-dry cycling of the boards was analysed as well. Temperature and moisture fluctuations negatively affected particleboard behaviour and properties. Strength dropped up to $50 \%$. Wider cracks in structure of the particleboards were detected by optical microscopy, namely in ITZ (internal transition zone) of cement matrix and spruce chips.
\end{abstract}

Keywords: Cement-bonded particleboard, Modification, Composition, Water saturation, Wet-dry cycle, Dynamics, Volume, Mass, Strength, Sugar content, Microstructure

\section{Introduction}

Particleboards are composite materials consisting of small wood particles bonded by a matrix [1]. There are many binders being used, including cement-based ones. Wang et al. [2] investigated a mixture that consisted of waste wood bonded by magnesium phosphate cement. Miranda de Lima et al. [3] presented research into the modification of binders by metakaolin and calcined ceramics. Caprai et al. [4] dealt with the substitution of

\footnotetext{
*Correspondence: melichar.t@fce.vutbr.cz

Institute of Technology of Building Materials and Components, Faculty of Civil Engineering, Brno University of Technology, Brno, Czech Republic
}

cement by MSWI (municipal solid waste incineration) bottom ash. The wood particles may come from many different kinds of wood, as documented by the findings of Odeyemi et al. [1] (African balsam tree), Nadhari [5] (banana trunk), A.N. Papadopoulos [6] (Carpinus betulis L.), Sotannde et al. [7] (Afzelia africana wood residues), Fuwape et al. [8] (tropical wood), Borysiuk et al. [9] (sugar beet pulp), Taha et al. [10] (tomato stalk), Amiandamhen and Izekor [11] (Gmelina arborea wood), Hossain et al. $[12]$ a Wang $[13,14]$ (construction wood waste), Cabral et al. [15] (stalk particles of Jerusalem Artichoke), Karade et al. [16] (lignocellulosic wastes), Sassoni et al. [17] (hemp) and Schwarzova et al. [18, 19] (hemp fibres).
Springer Open (c) The Author(s) 2021. Open Access This article is licensed under a Creative Commons Attribution 4.0 International License, which permits use, sharing, adaptation, distribution and reproduction in any medium or format, as long as you give appropriate credit to the original author(s) and the source, provide a link to the Creative Commons licence, and indicate if changes were made. The images or other third party material in this article are included in the article's Creative Commons licence, unless indicated otherwise in a credit line to the material. If material is not included in the article's Creative Commons licence and your intended use is not permitted by statutory regulation or exceeds the permitted use, you will need to obtain permission directly from the copyright holder. To view a copy of this licence, visit http://creativecommons.org/licenses/by/4.0/. 
The properties of wood and the cement matrix are markedly different. Wood is a heterogeneous material consisting mostly of structural components (cellulose, hemicellulose, and lignin) and non-structural components (polysaccharides of starch, extractives, proteins, some water-soluble organic compounds, and inorganic compounds). Wood is susceptible to volume changes due to moisture. Wood can hold water in the cell walls as bound water or in the cell cavities as free water [20]. In theory, most, if not all, of the hydroxyl groups in hemicelluloses are accessible to moisture [21]. Christensen and Kelsey [22] estimated that cellulose, hemicelluloses and lignin in Eucalyptus regnans are responsible for approximately $47 \%, 37 \%$ and $16 \%$ of the total water sorption of this wood species. The use of wood in cement composites is also strongly influenced by the leaching of hemicellulose, which slows the hydration rate of the cement matrix; cf. Janusa et al. [23].

However, with the proper treatment, the properties of wood can be at least somewhat stabilized against the effect of moisture or the unwanted extraction of hemicellulose. The modification of wood in cement-bonded particleboards has already been the subject of research by Sotannde et al. [7] (modification by $\mathrm{CaCl}_{2}, \mathrm{MgCl}_{2}$, and $\mathrm{AlCl}_{3}$ ), Makarona et al. [24] (nanostructured $\mathrm{ZnO}$ coating), Ahmed et al. [25] (oil impregnation, thermal modification), and Pelaez-Samaniego et al. [20] (thermally modified acacia and sesendok). Lee et al. [26] conclude that a particleboard made with higher proportion of oil palm trunk particles has better dimensional stability than that with higher proportion of rubberwood particles. Nasser et al. [27] analysed the pre-treatment of the particles with either cold or hot water and the addition 3\% of $\mathrm{CaCl}_{2}, \mathrm{Al}_{2}\left(\mathrm{SO}_{4}\right)_{3}$, or $\mathrm{MgCl}_{2}$ (by cement weight) in terms of its influence on the properties of the particleboards, specifically boards made with the pruning wastes from six wood species. Interactions between wood species and the $\mathrm{W} / \mathrm{C}$ (water/cement) ratio were highly significant for all of mechanical properties and dimensional stability characteristics. Treatment by hot water and $\mathrm{CaCl}_{2}$ was investigated by Amiandamhen and Izekor [11]. Their research also aimed to determine how the treatment of the wood (flakes and sawdust of Gamelina arborea) influences the strength, modulus of elasticity, water absorption, and swelling in thickness of the particleboards after $24 \mathrm{~h}$ in a water bath [11]. Li et al. [28] reached the conclusion that the vapour diffusivity of wood-cement composites decreases when the water content increases as a result of capillary condensation. Liquid diffusivity dramatically increases because of the high relative humidity at which the liquid water tends to saturate the pores, which allows the water to be free and thus to diffuse more easily [28]. Lee [26], drawing on Sulaiman [29], found that rubber wood is more hygroscopic than oil palm trunk. Pelaez-Samaniego [20] confirmed that the main factor contributing to the improvement of dimensional stability of particleboards of wood composites is the removal of hemicelluloses from the wood.

Currently there are several by-products (from cementbonded particleboard production) that lack any further utilization and are therefore discarded as waste. The most promising of these materials is dust produced by the cutting and grinding of the boards (6500 $\mathrm{t} /$ year) and a leftover particulate mixture consisting of cement, wood chips, admixtures, etc. (1000 t/year). Both the dust (D) and the particulate $(\mathrm{P})$ contain cement and spruce chips. These materials could potentially be re-used in the production of new cement-bonded particleboards. A survey of available literary sources and particleboard manufacturers has revealed that the re-use of the above-mentioned materials is still a largely unexplored area. Similarly, authors who have investigated the water absorption of particleboards have failed to produce a more complex and detailed analysis. Studies usually limit themselves to testing the compliance of materials with the requirements of technical standards [30-39].

\section{Materials}

Cement-bonded particleboards were manufactured by CIDEM Hranice, a.s. The batch per every test mixture was $11 \mathrm{~m}^{3}$. The reference mixture represents a standard market-available particleboard. Two more mixtures were designed, both modified by alternative components produced as by-products during the particleboard manufacturing process. The modification took into account prior research conducted in collaboration with CIDEM Hranice, a.s.; see [40, 41]. Components $\mathrm{D}$ and $\mathrm{P}$ were not treated (milling, crushing, sifting, etc.). Composition of designed mixtures is shown in the Table 1 (CP-R-reference particleboards; CP-D-particleboards modified by dust $\mathrm{D}$; $\mathrm{CP}-\mathrm{P}-$ particleboards modified by particulate mixture $\mathrm{P}$ ).

Table 1 Volume composition (\%) of designed mixturesreference and modified by dust and particulate mixture

\begin{tabular}{lccc}
\hline Component & $\begin{array}{l}\text { Mixture } \\
\text { CP-R }\end{array}$ & $\begin{array}{l}\text { Mixture } \\
\text { CP-D }\end{array}$ & $\begin{array}{l}\text { Mixture } \\
\text { CP-P }\end{array}$ \\
\hline Cement & 25.00 & 24.75 & 24.00 \\
Spruce chips & 63.00 & 59.22 & 60.48 \\
Dust-D & 0.00 & 4.03 & 0.00 \\
Particulate mixture-P & 0.00 & 0.00 & 3.52 \\
Water & 10.00 & 10.00 & 10.00 \\
Admixtures & 2.00 & 2.00 & 2.00 \\
\hline
\end{tabular}


The mixtures are based on blended cement CEM II/AS 42,5 R (Českomoravský cement, a.s., Mokrá, Czech Republic; specific surface area of $458 \mathrm{~m}^{2} / \mathrm{kg}$; density $3124 \mathrm{~kg} / \mathrm{m}^{3}$; initial set $215-250 \mathrm{~min}$; 28-day strength $59 \mathrm{MPa}$ ). The structure and microstructure of the wood chips are shown in Figs. 1 and 2. Their particle size distribution curve is in the chart below along with the other materials (Fig. 3). Besides these components, the mixtures also contained water and hydration-control admixtures.

The dust $\mathrm{D}$ is formed during cutting by a format saw, from where it is suctioned away via a cyclone that separates it from coarser particles. The particulate mixture $\mathrm{P}$ is created, for instance, by changes made to the manufacturing process, such as when the mixture is adjusted in response to weather conditions, etc. Analysis of D and P microstructure (Fig. 2) has revealed a very thorough mineralization of a large number of spruce chips. Cement matrix residues (hydration products) are present on wood chips surface. It is therefore evident that the wood chips are to a large extent sealed against the ingress of moisture. The properties of the alternative components $\mathrm{D}$ and $\mathrm{P}$ have already been analysed by Melichar et al. [40-42]. Particle size distribution of $\mathrm{P}$ and $\mathrm{D}$ is shown in Fig. 3.

The chemical and mineralogical composition of $\mathrm{D}$ and $\mathrm{P}$ corresponds to the composition of a productionline particleboard. The dust D has a larger wood content (determined by TOC analysis; Table 2).

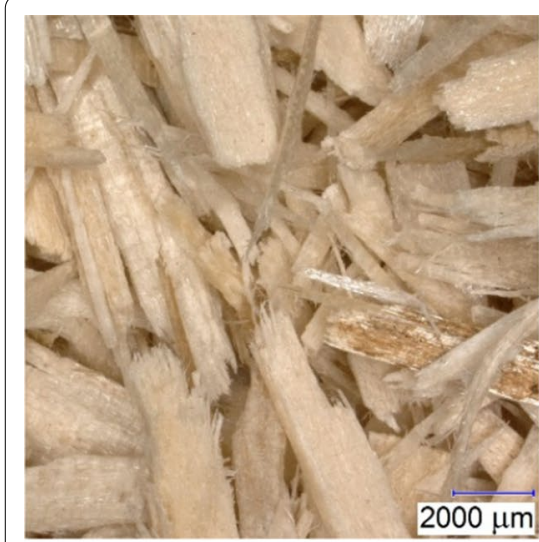

(a)

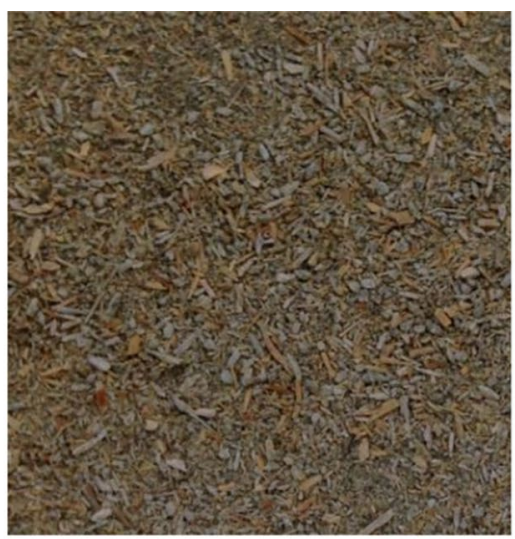

(b)

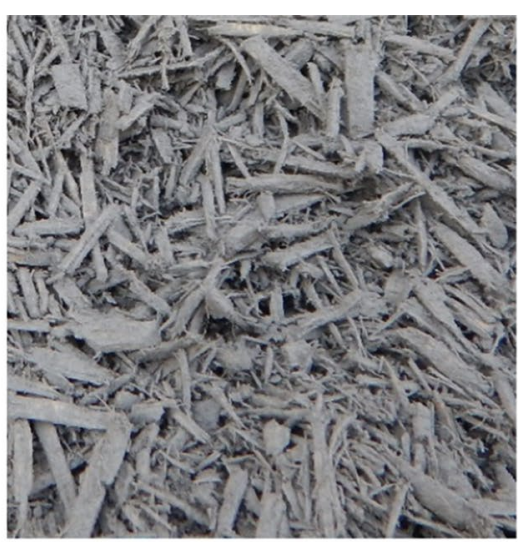

(c)

Fig. 1 Structure of: a the raw spruce chips; $\mathbf{b}$ dust $D ; \mathbf{c}$ particulate mixture $P$

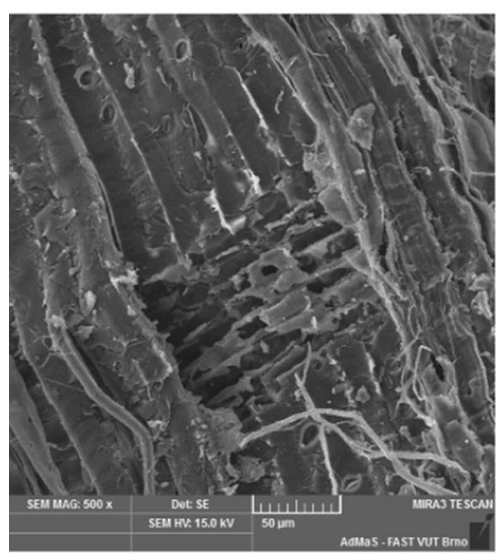

(a)

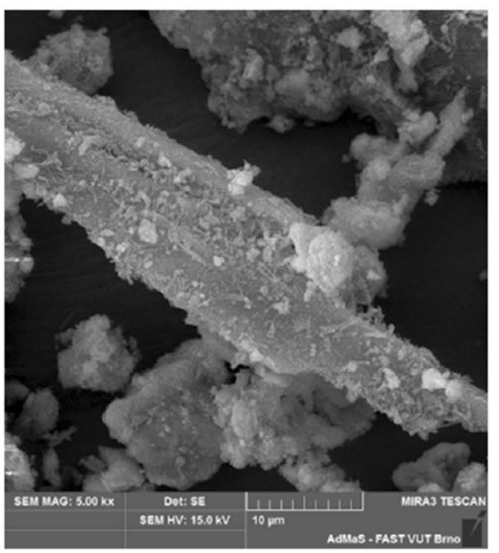

(b)

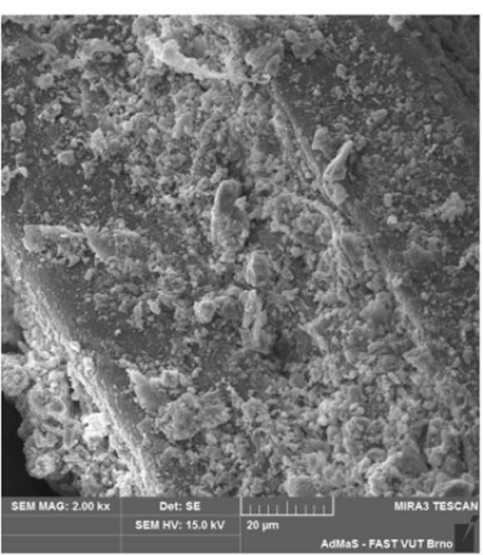

(c)

Fig. 2 Microstructure of wood chips: a the raw spruce chips mag. $500 \times$; b wood particle in dust D mag. $5000 \times$; c wood particle in particulate mixture P mag. 2000 x; pictures taken by a Tescan MIRA3 XMU scanning electron microscope 


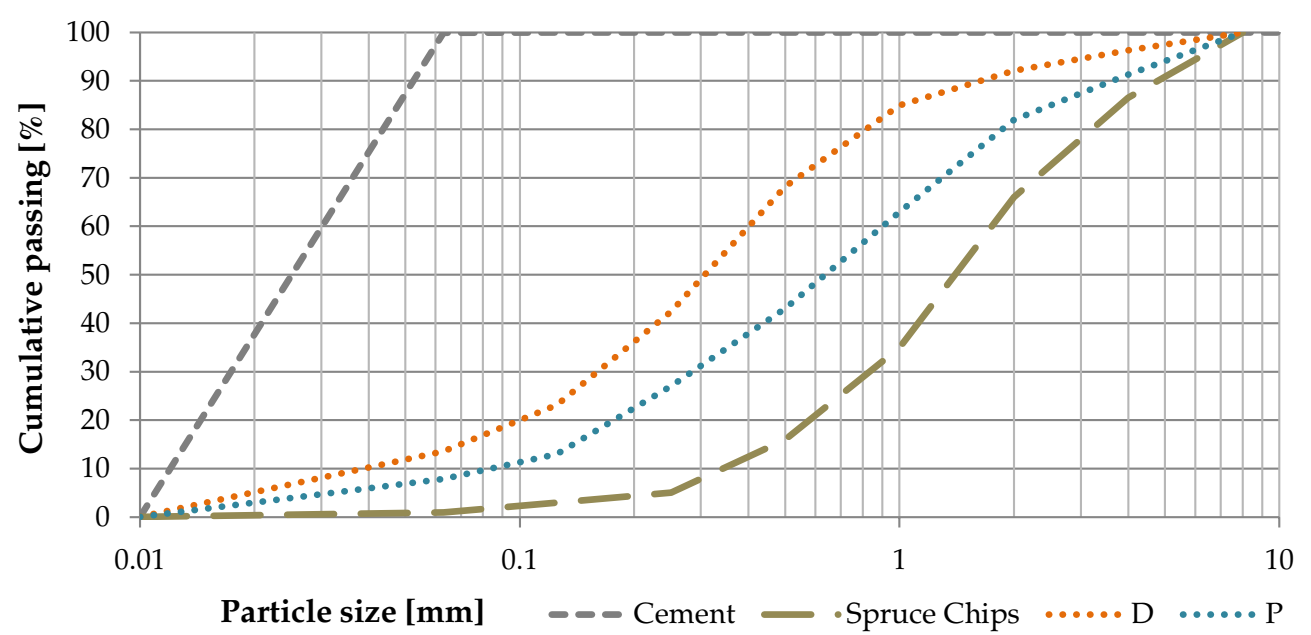

Fig. 3 Particle size distribution of the alternative components with the primary raw materials

Table 2 Chemical composition, wood content and water absorption of D and $\mathrm{P}$

\begin{tabular}{llllllll}
\hline Alternative material & $\begin{array}{l}\mathrm{SiO}_{2} \\
{[\%]}\end{array}$ & $\begin{array}{l}\mathrm{CaO} \\
{[\%]}\end{array}$ & $\begin{array}{l}\mathrm{Al}_{2} \mathrm{O}_{3} \\
{[\%]}\end{array}$ & $\begin{array}{l}\mathrm{Fe}_{2} \mathrm{O}_{3} \\
{[\%]}\end{array}$ & $\begin{array}{l}\mathrm{Na}_{2} \mathrm{O}_{1} \mathrm{~K}_{2} \mathrm{O} \\
{[\%]}\end{array}$ & $\begin{array}{l}\text { Wood content } \\
{[\%]}\end{array}$ \\
\hline $\mathrm{D}$ & 10.5 & 46.1 & 14.8 & 3.8 & 0.4 & 26.1 & WA [\%] \\
$\mathrm{P}$ & 14.9 & 41.9 & 13.9 & 4.4 & 1.2 & 19.8 & 49.9 \\
\hline
\end{tabular}

\section{Experimental methods}

The particleboards with density $1300-1400 \mathrm{~kg} / \mathrm{m}^{3}$ and $12 \mathrm{~mm}$ in thickness were made and cut into specimens at the production line at CIDEM Hranice, a.s. 28 days later the boards were transported to the laboratories of the Institute of Building Materials and Components, Faculty of Civil Engineering, BUT. Specimens matured for roughly 17 months in the laboratories. All the tests and analyses were planned so that their end would coincide with the specimens reaching 18 months of age.

\section{Specimen preparation and dimensions}

Specimens with the dimensions of $50 \mathrm{~mm} \times 50 \mathrm{~mm} \times 12 \mathrm{~mm}$ (water saturation dynamics up to $30 \mathrm{~min}), 290 \mathrm{~mm} \times 50 \mathrm{~mm} \times 12 \mathrm{~mm}$ (testing of mechanical properties), and $300 \mathrm{~mm} \times 100 \mathrm{~mm} \times 12 \mathrm{~mm}$ (dimensional and mass changes) were made. All the specimens were stored in a climate chamber until they reached a stable mass. Afterwards the specimens were placed in an exicator for temperature stabilization. Next, all the dimensions (length, width, and thickness) as well as mass were measured. Also detailed images of the specimen structure were taken using an optical microscope. Each individual parameter was determined using a set of 6 specimens where 3 specimens were cut from the boards in the longitudinal and 3 in the transverse direction.

\section{Analysis of structure-computed tomography}

Before the water saturation, three-dimensional structure of CP-R particleboard was analysed. This non-destructive analysis was focused on identification of prevailing direction and orientation of spruce chips in the boards. Orientation of wood chips is important due to different behaviour during dimensional changes related to water saturation. XRD tomography device phoenix v|tome $\mid \mathrm{x} \mathrm{m}$ 300 was used for this purpose.

\section{Water saturation, swelling}

Standard EN 317 [34] determines swelling in the thickness of a specimen after being completely submerged under water at $(20 \pm 1){ }^{\circ} \mathrm{C}$. In principle, the experiment followed EN 317. The standard only observes changes in thickness. The presented research examined volume changes in greater detail, including changes in length and width. The specimens had dimensions of $300 \mathrm{~mm} \times 100 \mathrm{~mm} \times 12 \mathrm{~mm}$ (see Fig. 4), which is similar to those of particleboards used in real-life applications. Besides dimensional changes, mass increases were observed as well. The standard EN 634-2 [32] only examines the value of swelling in thickness $24 \mathrm{~h}$ after 


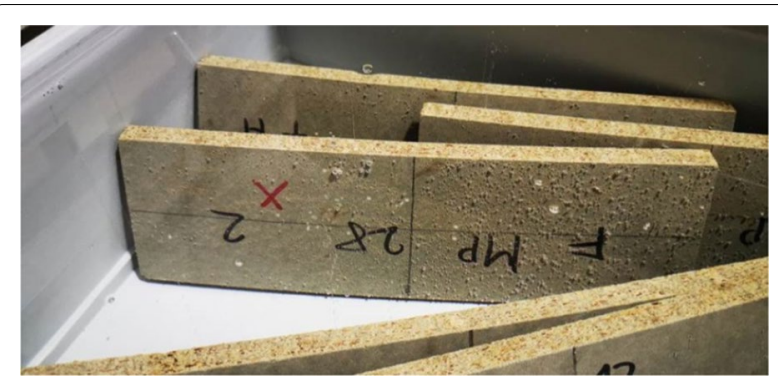

Fig. 4 Cement-bonded particleboard specimens about $1 \mathrm{~h}$ after immersion in water at approximately $20^{\circ} \mathrm{C}$. The specimens were used to assess the dynamics of moisture saturation

full immersion in water. The above-mentioned properties (dimensions and mass) were measured at $0,1,4,6,8$, $12,24,48,72,96,168,336$, and $504 \mathrm{~h}$ for a more detailed determination of the water saturation dynamics.

The specimens were maintained in laboratory environment after their removal from the water. Gradual drying of the tested particleboards occurred till the stable weight was reached. Subsequently, irreversible changes of monitored parameters were determined.

\section{Wet-dry cycling}

Conditions characterized by cyclic wetting and drying were simulated in water bath and drying oven. One cycle (total $48 \mathrm{~h}$ ) consisted of two follow-up phases-immersion in water at $20{ }^{\circ} \mathrm{C}$ for $24 \mathrm{~h}$; drying in oven at $103{ }^{\circ} \mathrm{C}$ for $24 \mathrm{~h}$. A total of 7 such cycles were performed. Mass and dimensions were determined after each cycle. Evaluation of reversible, irreversible changes and macroscopic failures was possible.

\section{Leachability of sugars}

Cement-bonded particleboards contain sugars, mainly hemicellulose, which has negative effect on cement matrix hardening. Hemicellulose is dissoluble in presence of water. Thus, the water from the bath (where the specimens were stored) was sampled after 168 and $504 \mathrm{~h}$ and tested for sugar content. The sugar content determination (Fig. 5) followed the principle of reducing sugar with potassium permanganate $\left(\mathrm{KMnO}_{4}\right)$ in an alkaline environment. The reduction of $\mathrm{Mn}^{\mathrm{VI}}$ to $\mathrm{Mn}^{\mathrm{IV}}$ changes the colour of the solution to yellow or yellow-brown. Brown $\mathrm{MnO}_{2}$ precipitate may form at high permanganate concentrations.

\section{Density, bending and tensile properties}

Three sets of specimens were tested. One reference set was tested. The second set contained particleboards that were saturated by moisture (up to $504 \mathrm{~h}$ ) and subsequently dried in laboratory conditions. The last set consisted of particleboards that were exposed to wet-dry cycles. Their dimensions were $50 \mathrm{~mm} \times 50 \mathrm{~mm} \times 12 \mathrm{~mm}$ (density, tensile) and $290 \mathrm{~mm} \times 50 \mathrm{~mm} \times 12 \mathrm{~mm}$ (bending). Before the tests of physical and mechanical properties were conducted, the particleboard specimens were stored at relative humidity of $(65 \pm 5) \%$ and temperature $(20 \pm 2){ }^{\circ} \mathrm{C}$ to allow them to reach stable mass.

The method for determining the density of particleboards is described in EN 323 [37]. Bending strength and modulus of elasticity in bending were determined according to EN 310 [33] (the three-point bend test). The strength of the specimen is calculated as the ratio between the bending moment $M$ at maximum load $F_{\text {max }}$ and the moment of the whole cross-section. The distance between the centres of the two support rollers is set at $20 \times$ the thickness of the board. The maximum load (specimen failure) must occur no later than $(60 \pm 30) \mathrm{s}$ at a constant loading rate. Tensile strength perpendicular to the plane of the board was determined from the maximum force acting upon the specimen surface according to EN 319 [36]. The loading rate was set so that the specimens would suffer failure within $(60 \pm 30) \mathrm{s} ; 3 \mathrm{~mm} / \mathrm{min}$.

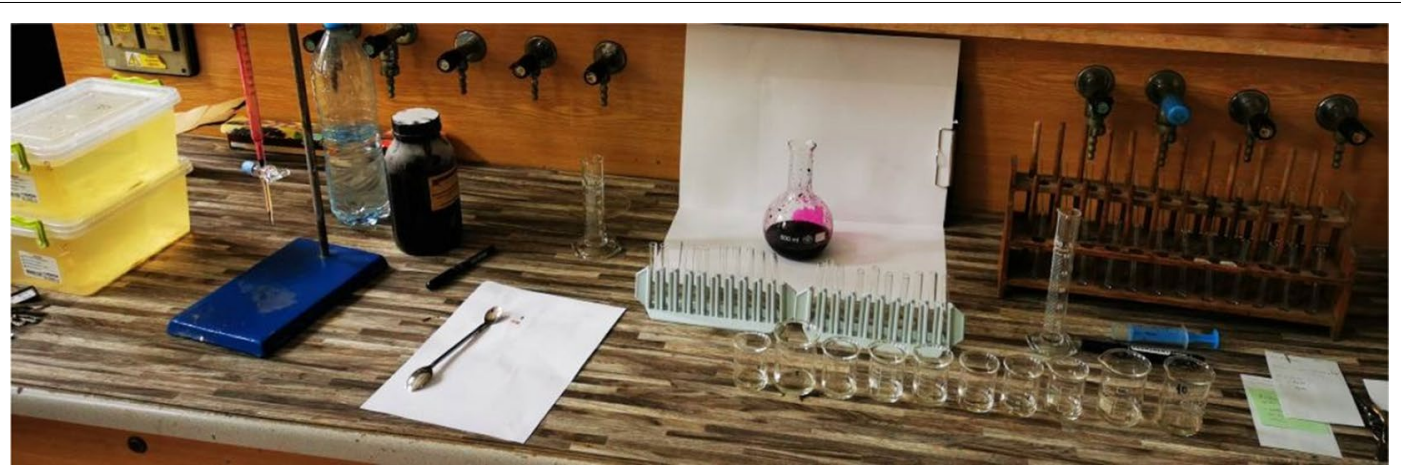

Fig. 5 Analysis of sugar concentration in the water solution in which the specimens were immersed for $504 \mathrm{~h}$ 


\section{Microstructural analysis-optical microscope}

The structural changes were analysed with a Keyence VHX-950F optical microscope (up to $200 \times$ magnification). Special attention was paid mainly to areas where cracks had formed, as these parts make it possible to see how moisture saturation influences the dimensional or volumetric changes of the boards. The analysis focused mainly on the moisture saturation dynamics of the cement-bonded particleboards and its role in the closing and subsequent re-occurrence of microcracks. The moisture saturates the cell walls of the wood chips, which causes it to swell and cause microcracks to form in the cement matrix. A total of 3 sets of specimens were subjected to a detailed analysis. The first set was examined from 0 through $30 \mathrm{~min}$ after immersion and consisted of specimens with the dimensions of $50 \mathrm{~mm} \times 50 \mathrm{~mm} \times 12 \mathrm{~mm}$. The microstructural analysis of these specimens took place while they remained immersed in water (see Fig. 6). The second set comprised specimens of $300 \mathrm{~mm} \times 100 \mathrm{~mm} \times 12 \mathrm{~mm}$, which were examined at a set time interval together with weighing and dimension measurement; i.e. before water saturation and after $1,4,6,8,12,24,48,72,96$, and $168 \mathrm{~h}$ under water. The third set comprised specimens of $300 \mathrm{~mm} \times 100 \mathrm{~mm} \times 12 \mathrm{~mm}$ which were analysed during wet-dry cycles, i.e. each $24 \mathrm{~h}$ (after water saturation and also after drying).

\section{Results and discussion}

\section{D structure of the particleboards}

Following figures (Figs. 7 and 8) show CP-R board with emphasis on orientation of spruce chips. Orientation of chips in the particleboards is important in terms of dimensional changes because wood is an anisotropic material. Significant dimensional and volume changes occur in radial and tangential direction of wood [24, 43].

$\mathrm{CT}$ analysis proved that axial direction of the chips is mostly parallel with plane of the particleboard. Radial and tangential direction of the wood chips is oriented perpendicular to the length (linear direction) of the particleboards. Thus, the most apparent dimensional changes could occur in thickness direction.

\section{Dynamics of water saturation}

The charts (Fig. 9) show a detailed evaluation and comparison of the dimensions, mass, and volume of the particleboard specimens (development up to $504 \mathrm{~h}$ ). Irreversible changes of tested parameters after gradual drying in laboratory environment are shown in Table 3. Results confirmed diverse behaviour of boards in dependence on their composition during soaking. This relates to different ratio of cement and chips in CP-R, CP-D and CP-P. Ratio of cement, chips and alternative raw materials also has effect on structure of ITZ of matrix and spruce chips. The sorption of the boards not only occurs separately in spruce chips and cement matrix, but it is also complicated by the interfacial region [44]. Sorption dynamics, characterized by rapid changing dimensions and mass, is apparent up to $96 \mathrm{~h}$ of soaking. The most rapid change was determined after the first hour of the immersing boards. This indicates relatively open porous structure of the boards when the first water penetrates through cement matrix capillary system into the cell structure of spruce chips. Penetration of water is more difficult with increasing water amount within the boards, because porous structure is gradually filled by the water and less

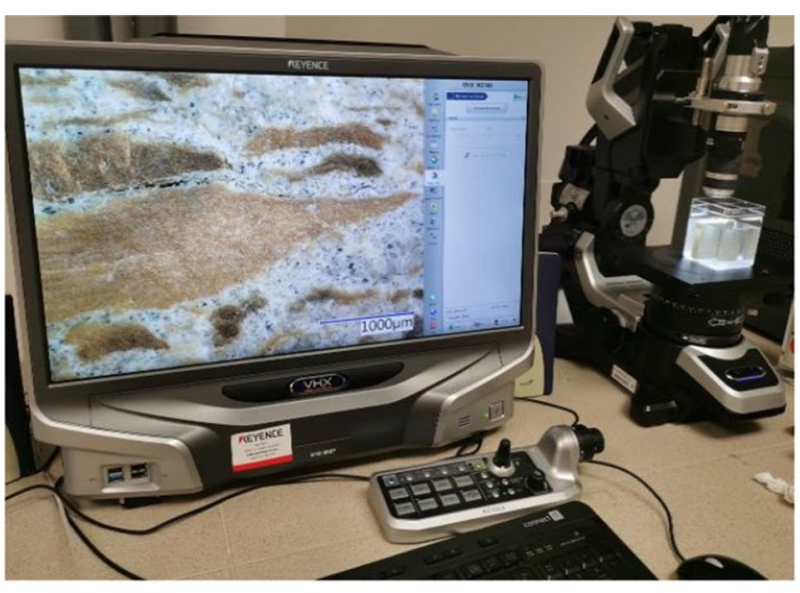

(a)

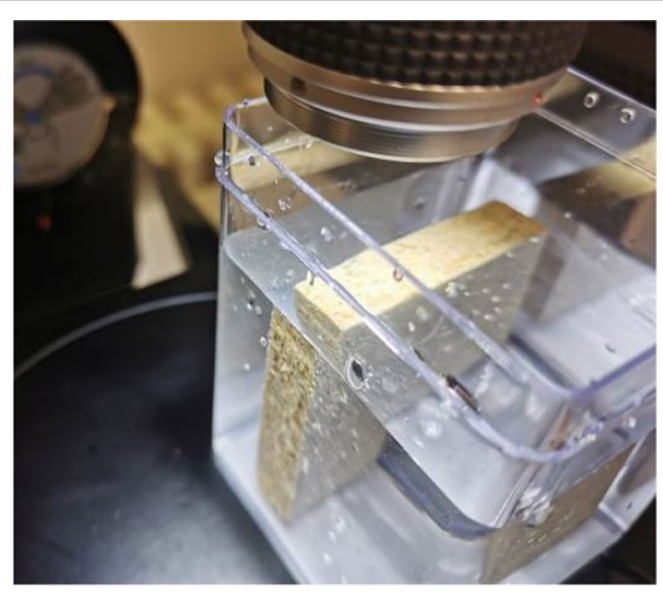

(b)

Fig. 6 Observation and evaluation of volume changes in a specimen being saturated by liquid moisture using an optical microscope: a the microscope with a specimen; $\mathbf{b}$ specimen detail under the lens of the microscope 


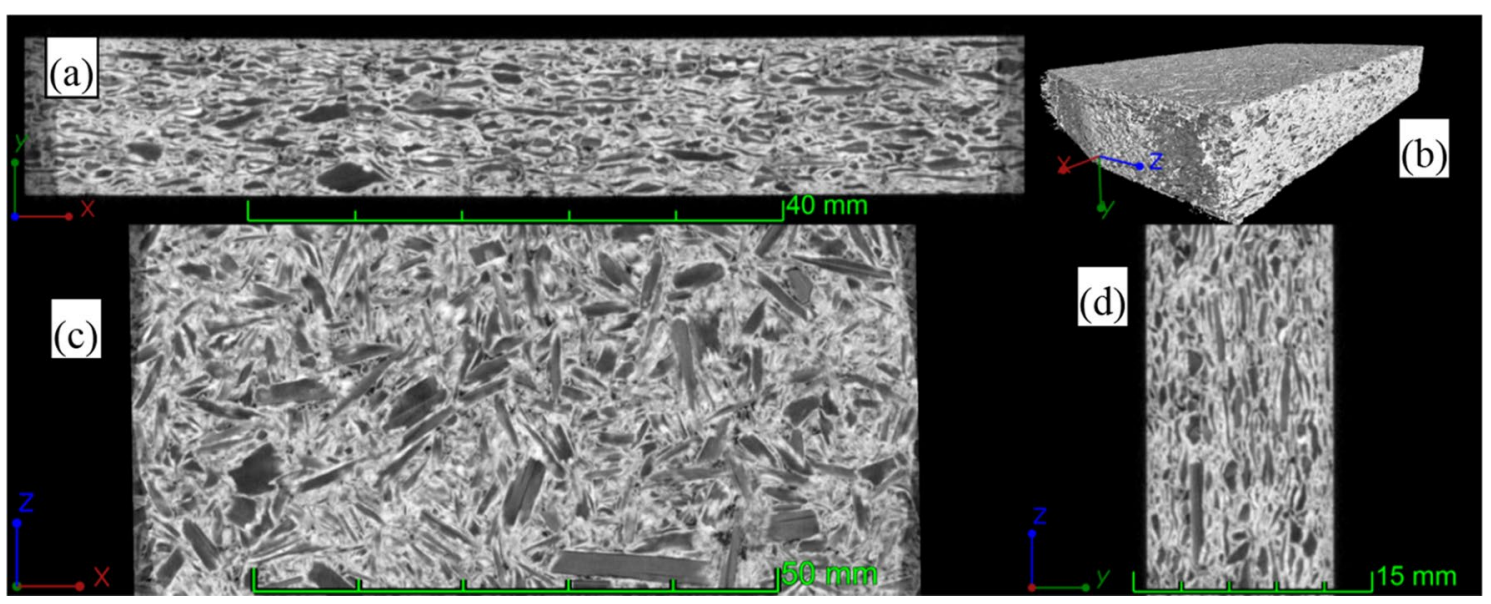

Fig. 7 Structure of board CP-R—CT analysis; orientation of spruce chips: a longitudinal slice—perpendicular to the plane of the board; $\mathbf{b} 3 \mathrm{D}$ model; c longitudinal slice —in plane of the board; $\mathbf{d}$ transversal slice

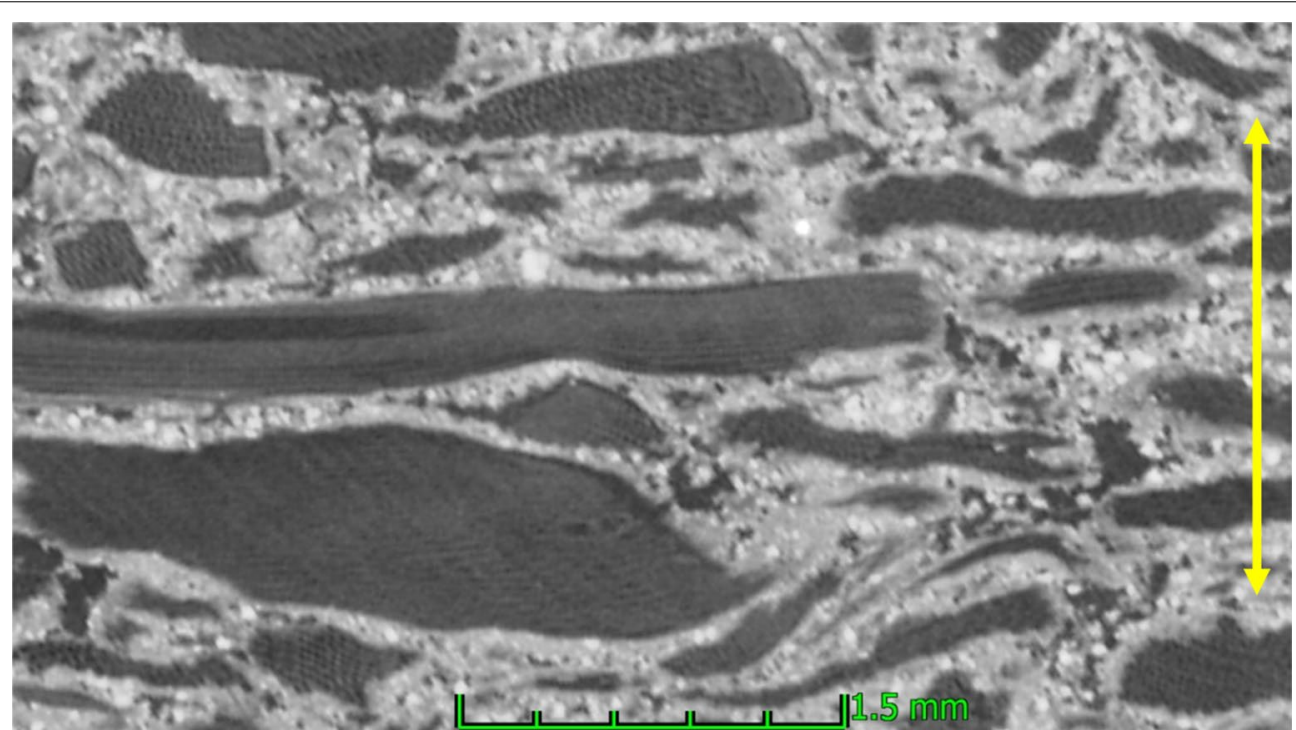

Fig. 8 Structure of board CP-R-CT analysis; orientation of spruce chips—detail. Direction of thickness and pressure effecting during production of boards-yellow crowfoot

free space remains. Therefore, another penetration of water into the boards slows down. When fibre saturation point (FSP-fully saturated cell walls of wood) is reached, dimensional and volumetric changes are not so significant. However, it is quite difficult to determine exactly FSP of spruce chips in the boards with regard to heterogeneous structure of this composite material (cement matrix, spruce chips, ITZ). The spruce chips are also stabilized (modified) by water glass, $\mathrm{Ca}$ ions of cement binder and thermal treatment during the production of boards. This stabilization of the chips perceptibly changes their sorption dynamics. Reference boards CP-R show the most stable properties in terms of dimensional, volume and mass changes. Irreversible changes of the tested parameters were determined in case of all types of boards. Irreversible mass changes of CP-R correspond to findings Fan et al. [45].

The linear direction is characterized by the smallest dimensional changes ( $0.39 \%$ CP-P; Fig. 9a). This relates to the orientation of spruce chips in the particleboards and direction of pressure during production of the boards (Figs. 7 and 8), including residual stress in the chips. Residual stress did not affect linear expansion strongly. Length change $0.23 \%(\mathrm{CP}-\mathrm{R}), 0.28 \%$ (CP-D) and $0.29 \%$ 


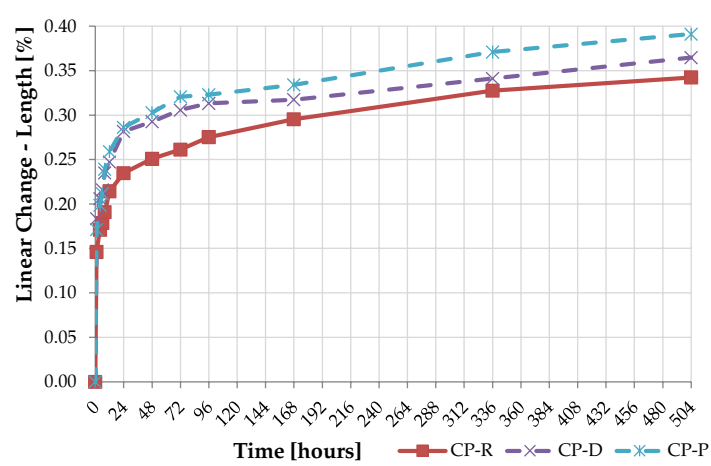

(a)

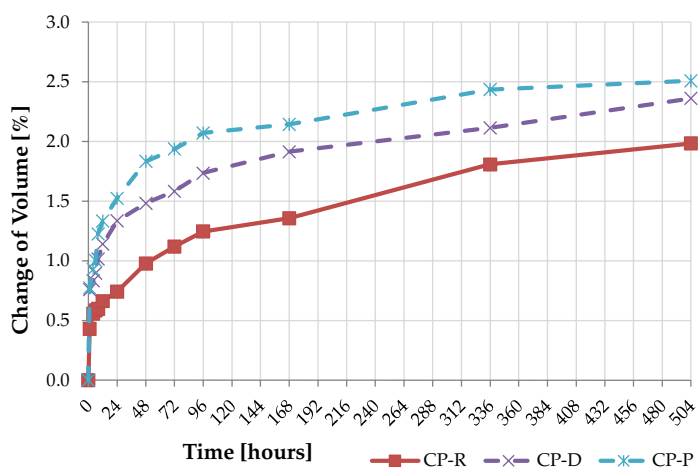

(c)

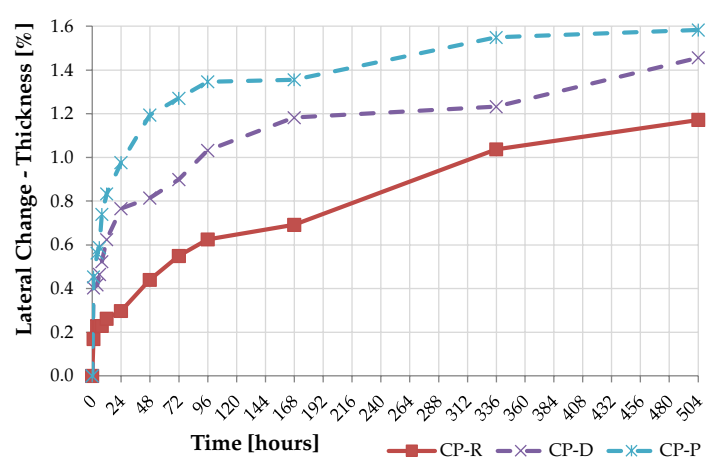

(b)

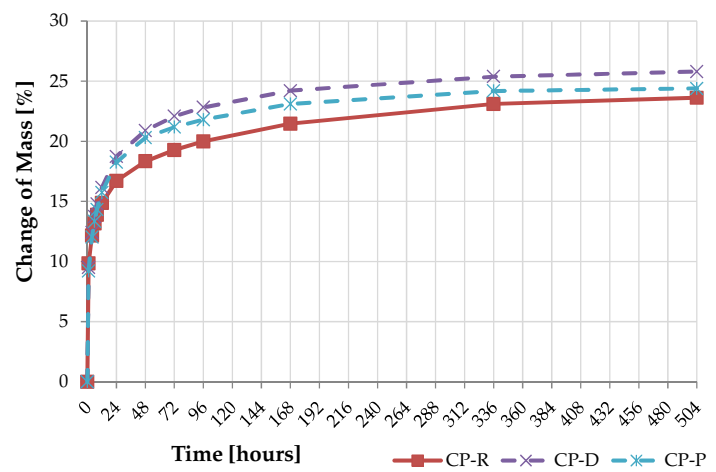

(d)

Fig. 9 Dimensional, volume and mass the changes of the boards during water saturation over the total of $504 \mathrm{~h}$ : $\mathbf{a}$ linear-length change; $\mathbf{b}$ lateral - thickness change; c volumetric change; $\mathbf{d}$ mass change

Table 3 Irreversible changes of dimensions, volume and mass of tested cement-bonded particleboards

\begin{tabular}{lllll}
\hline Mixture-boards & $\begin{array}{l}\text { Linear-length } \\
{[\%]}\end{array}$ & $\begin{array}{l}\text { Lateral- } \\
\text { thickness } \\
{[\%]}\end{array}$ & $\begin{array}{l}\text { Volume } \\
{[\%]}\end{array}$ & $\begin{array}{l}\text { Mass } \\
{[\%]}\end{array}$ \\
\hline CP-R & 0.10 & 0.26 & 0.69 & 1.20 \\
CP-D & 0.14 & 0.26 & 0.99 & 3.01 \\
CP-P & 0.15 & 0.35 & 1.38 & 3.14 \\
\hline
\end{tabular}

(CP-P) was determined after 24 h of soaking. After gradual drying, irreversible linear change was determined in range of $0.10 \%$ to $0.15 \%$.

Radial and tangential swelling occurs mostly in thickness direction of the boards due to the chips orientation. Also residual stress (from production of the boards) in the chips is relaxed during their soaking. This stress causes increasing expansion pressure of spruce chips and thus strongly affects thickness change. Therefore, compared to the linear changes, much higher values of swelling in thickness were determined (see Fig. 9b) CP-P (1.58\% after $504 \mathrm{~h})$. After $24 \mathrm{~h}$, the CP-R specimens swelled by $0.3 \%$, which corresponds to the information declared by the manufacturer [46]. The dynamics of water saturation in case of CP-P is the most apparent up to $96 \mathrm{~h}$ of soaking. CP-R shows a more significant increase between 168 and 504 h. After gradual drying, irreversible change of thickness was determined in range of $0.26 \%$ to $0.35 \%$. Particleboards CP-D and CP-P suffered from swelling in thickness after $24 \mathrm{~h}$ in a much smaller degree than particleboards containing other available agricultural waste (various plants and woods). This is supported by results-Nasser et al. [27] (4.51\% to 4.87\%), Odeyemi et al. [1] (2\%), Sotannde et al. [7] (0.8\% to $2.19 \%)$, Fuwape et al. [47] (4.44\%), Okino et al. [48] (1.1 to $1.8 \%$ ) and Zhou et al. [49] (0.53\%). Strong dependence of swelling in thickness on particleboards composition was proved. However, relationship between dimensional changes (see Fig. 9a,b) and density (see "Physical and mechanical parameters" section) of the particleboards was not proved, as for example Nasser et al. [27] present.

Volume changes (see Fig. 9c) roughly follow the trend of swelling in thickness (see Fig. 9b). Particleboard specimens CP-P appear the most susceptible to volume change with $1.52 \%(24 \mathrm{~h})$ and $2.51 \%(504 \mathrm{~h})$ during water 
saturation. The volume increases the most rapidly during the first $48 \mathrm{~h}$ of immersion. This is partially caused by the dissolution of soluble substances of the spruce chips, which may increase stress in the remaining wood substances and surrounding solids of cement paste. This leads to a corresponding volume change in both the wood chips and the adjacent cement paste [44]. Particleboards CP-D and CP-P exhibit the same volumetric behaviour over the first hour of soaking $(0.76 \%$ and $0.77 \%)$. After gradual drying, irreversible volumetric change was determined in range of $0.69 \%$ to $1.38 \%$. These values are not negligible considering the maximal volumetric changes after $504 \mathrm{~h}$.

The results show that differences between mass (Fig. 9d) of CP-R, CP-D and CP-P boards are smaller in comparison with the dimensional and volume changes. The most dramatic increase occurs within $1 \mathrm{~h}$ of initial immersion (approximately 10\%). After $504 \mathrm{~h}$ of immersion, the mass of all the specimens increased to a similar degree, ranging from $24.40 \%$ to $25.79 \%$. After gradual drying, irreversible change of mass was determined in range $1.20 \%$ to $3.14 \%$. The tested particleboards exhibit different water absorption depending on the type of alternative material used. The dynamics of mass change vary as well. This confirm results and findings related to water absorption after $24 \mathrm{~h}$ immersion by Sotannde et al. [7] (9.28-16.14\%), Nasser et al. [27] (13.4-21.3\%), Odeyemi et al. [1] (5.8\%), Fuwape et al. [47] (20.40\%), Savastano et al. [50] (10.7-24.8\%), Okino et al. [48] (14.4-16.7\%) and Zhou et al. [49] (6.9\%). The particleboards analysed by Okino et al. [48] show a more dynamic water saturation during the first two hours of initial immersion.

CP-D boards appear more resistant to moistureinduced changes than CP-P. The cause is partly due to the nature of the alternative components. Component $\mathrm{P}$ contains larger particles and aggregations of cement and wood chips. Another crucial factor is that dust D comes from particleboards that have passed through the entire manufacturing process, including two thermal curing cycles. On the contrary, particulate mixture $\mathrm{P}$ accumulates in the production line after mixing and layering into a continuous sheet. This means that component $\mathrm{P}$ has not completed its full mineralization cycle. Performed tests confirmed that the origin of the alternative component plays a significant part in the dimensional and volumetric changes. However, effect on water absorption (mass changes) of the particleboards is not so evident.

\section{Wet-dry cycling}

Effect of cyclic water soaking and drying on parameters of the particleboards was analysed (Fig. 10). Irreversible and reversible changes of the tested parameters after wet-dry cycling are apparent from Table 4. Linear changes are the smallest, with irreversible component approximately $-0.1 \%$. The differences between the CP-R, CP-D and CP-P are not significant. On the other hand, thickness change is more obvious and increase was noticed, while linear irreversible change is characterized by shrinkage. The differences in thickness between individual types of particleboards are more evident. Reference boards CP-R show the smallest dimensional, volume and mass changes. Boards CP-P are the most susceptible to the analysed parameters due to wet-dry cycles.

Irreversible swelling is caused by the release of the residual compressive stresses imparted to the board during the pressing process [47]. Relief of residual stresses within the wood due to hot pressing process was also presented by Rowell [51]. Composition of the particleboards also has significant effect on its changes during wet-dry cycles. Based on comparison of results [47] with outcomes in this study, very strong dependence on composition of the particleboards is obvious.

Boards CP-R, CP-D and CP-P show irreversible change in range of 0.40 to $0.74 \%$, whereas authors [47] determined irreversible changes of the particleboards in range 15 to $21 \%$. An interesting fact is that these different values are noticeable despite very similar density and cement/ particle ratio of the particleboards. Another key factor, affecting rate of changes, is de-bonding of the cement matrix and wood particles due to chips shrinkage during drying [47]. Failures between cement matrix and spruce chips are apparent from microscopic observation (see "Microstructure" section). Regarding to very low changes of CP-R, CP-D and CP-P it is evident that de-bonding effect is very slight in comparison with boards based on sawdust and wastepaper [47]. Irreversible changes of particleboards mass (growing trend) and length (downward trend) were determined by Fan et al. [45] during wet-dry cycles (90-65-35-65-90\% RH). Length and mass trend is obvious also from hysteresis loops (isotherms) [45].

Results (Fig. 10 and Table 4) are supported, among others, by Ahmed et al. [25]. Mass loss of the particleboards is connected with removal of water-soluble carbohydrates or extractives from spruce chips, especially after the first cycle (see Fig. 10d). Nevertheless, the mass loss is very low, i.e. $0.76 \%$. Mass and length trend (Fig. 10a and d) is confirmed also by Fan et al. [44]. Wood chips degradation in cement-bonded particleboards can occur due to highly alkaline environment (cement matrix). This causes loss of mass and dimensional changes (chips).

\section{Sugar leachability}

Negative effect of sugars during cement matrix hardening analysed and described among others [52-55]. Therefore the water (in which the specimens resided) was sampled after 168 and $504 \mathrm{~h}$ and tested for sugar content. 


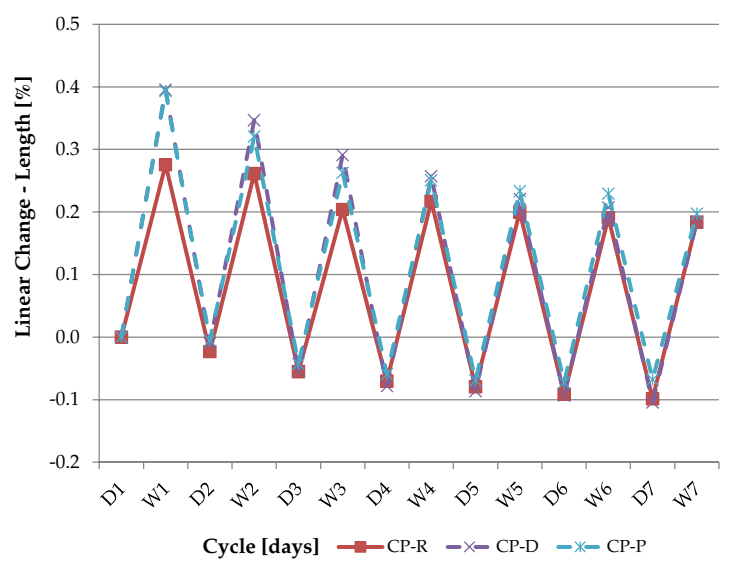

(a)

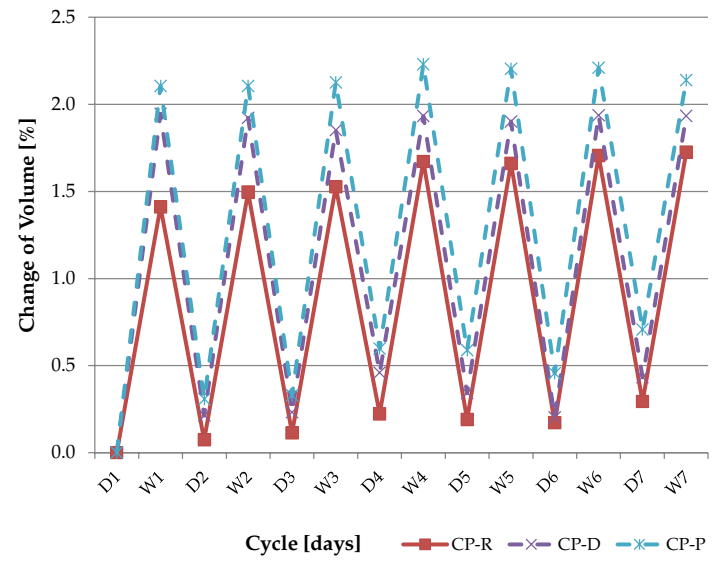

(c)

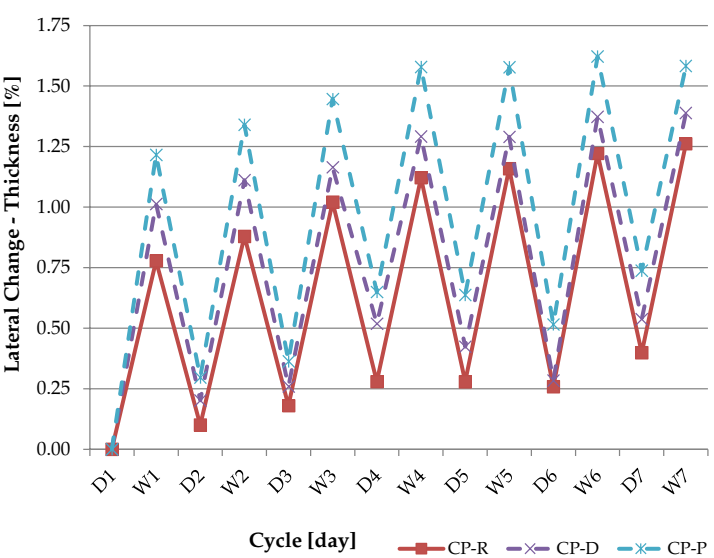

(b)

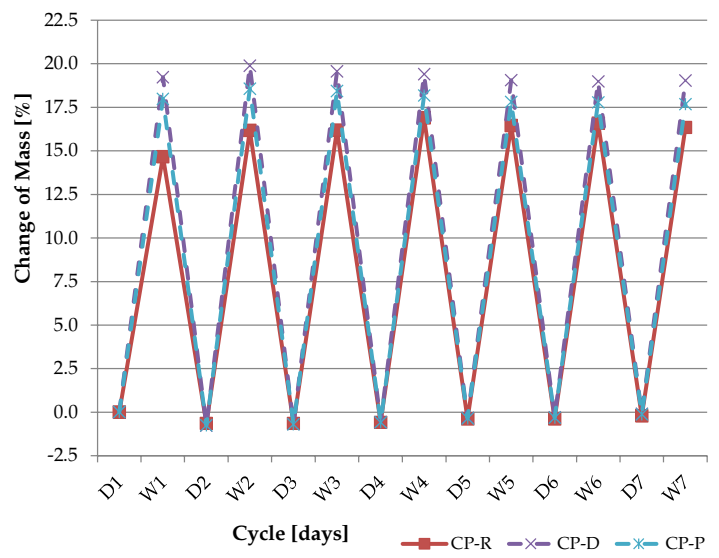

(d)

Fig. 10 Dimensional, volume and mass the changes of the boards during wet-dry cycling (7 cycles): a linear-length change; b lateral—-thickness change; $\boldsymbol{c}$ volumetric change; $\mathbf{d}$ mass change

Table 4 Irreversible changes of dimensions, volume and mass of tested cement-bonded particleboards

\begin{tabular}{lllll}
\hline Mixture-boards & $\begin{array}{l}\text { Linear-length } \\
{[\%]}\end{array}$ & $\begin{array}{l}\text { Lateral- } \\
\text { thickness } \\
{[\%]}\end{array}$ & $\begin{array}{l}\text { Volume } \\
{[\%]}\end{array}$ & $\begin{array}{l}\text { Mass } \\
{[\%]}\end{array}$ \\
\hline CP-R & -0.10 & 0.40 & 0.29 & -0.22 \\
CP-D & -0.08 & 0.54 & 0.43 & -0.09 \\
CP-P & -0.08 & 0.74 & 0.71 & -0.13 \\
\hline
\end{tabular}

By this time, the water had changed colour and taken on a yellow hue. Sugars inhibit the hydration of the cement matrix. Janusa et al. [23] claim that sugars at concentrations as low as $0.03-0.15 \%$ (originating from hemicellulose) will delay initial setting and strength gain in cement composites. Table 5 lists the measured values of sugar content in the eluate. Selected representative samples
Table 5 Sugar content in the water bath after 168 and $504 \mathrm{~h}$ of immersion of the cement-bonded particleboards

\begin{tabular}{|c|c|c|c|c|}
\hline Mixture & $\begin{array}{l}\text { Consumption } \\
\text { of } 2 \% \mathrm{KMnO}_{4} \\
\text { solution } \\
(168 \mathrm{~h}) \\
{[\mathrm{mL}]}\end{array}$ & $\begin{array}{l}\text { Sugar } \\
\text { content in } \\
\text { the leach } \\
(168 \mathrm{~h}) \\
{[\%]}\end{array}$ & $\begin{array}{l}\text { Consumption } \\
\text { of } 2 \% \mathrm{KMnO}_{4} \\
\text { solution } \\
(504 \mathrm{~h}) \\
{[\mathrm{mL}]}\end{array}$ & $\begin{array}{l}\text { Sugar } \\
\text { content in } \\
\text { the leach } \\
(504 \mathrm{~h}) \\
{[\%]}\end{array}$ \\
\hline CP-R & 0.75 & 0.008 & 3.00 & 0.030 \\
\hline CP-D & 1.25 & 0.013 & 5.00 & 0.050 \\
\hline CP-P & 1.00 & 0.010 & 3.25 & 0.033 \\
\hline
\end{tabular}

during analysis-see Fig. 11. Each of the specimen sets was placed in a separate water bath.

The results show that over $168 \mathrm{~h}$, only a very small amount of sugars had leached. Given the findings of Janusa et al. [23], this amount is too insignificant to 


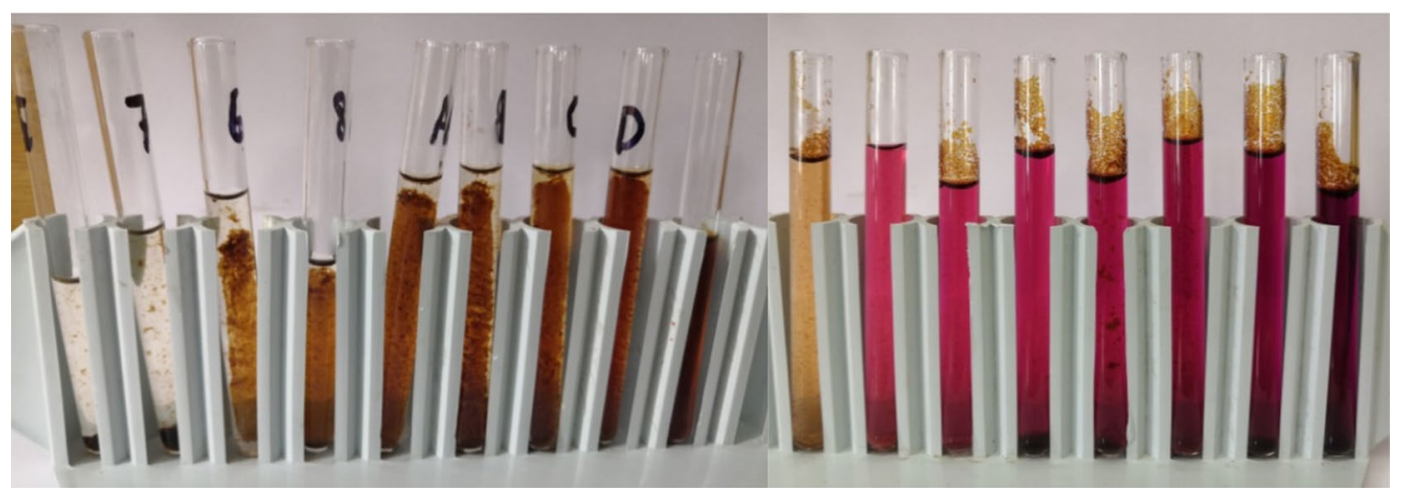

Fig. 11 Colour change indicating sugar content. The identified value for sugar content calculation was indicated by a light magenta colour

have any particular influence on cement hydration. A slightly higher amount of sugar was found in the water where the specimens remained for $504 \mathrm{~h}$. In the case of $\mathrm{CP}-\mathrm{R}$ and CP-P, this amount was at the bottom threshold of the sugar concentration given by Janusa et al. [23]. A higher amount was found only in the eluate of CP-D. The results of sugar concentration in the water bath correspond to the material composition of each mixture.

The results show that $504 \mathrm{~h}$ of moisture contact will cause sugar leaching that is capable of affecting the hydration of the cement matrix. $\mathrm{C}_{3} \mathrm{~A}$ reacts very rapidly. Therefore it can be assumed that sugar leaching of a rate that was observed within this experiment (see Table 1) is too slow to affect the $\mathrm{C}_{3} \mathrm{~A}$ reaction. It is more likely that the sugars would affect the $\mathrm{C}_{3} \mathrm{~S}$ reaction. However, this clinker mineral also reacts relatively quickly. Especially when a large amount of water is present, it is very likely that $\mathrm{C}_{3} \mathrm{~S}$ will have reacted before enough sugars have leached to slow it down.

\section{Physical and mechanical parameters}

The density values of all the specimens are shown in Fig. 12a (ranging between 1320 and $1350 \mathrm{~kg} / \mathrm{m}^{3}$ ). Immersion in the water bath has increased these values to 1350 to $1380 \mathrm{~kg} / \mathrm{m}^{3}$. Slight decrease of density was determined in case of the boards subjected to the wet-dry cycles, values in range of 1300 to $1320 \mathrm{~kg} / \mathrm{m}^{3}$.

Bending strength tests have revealed a slight benefit of the water immersion, but very significant deterioration due to wet-dry cycling (see Fig. 12b). The bending strength and density of reference and immersed boards has similar trend. The bending strength of specimens matured in a normal environment ranges between 12.3 and $12.7 \mathrm{~N} / \mathrm{mm}^{2}$. Prolonged immersion in water has increased these values by 1.3 to $4.1 \%$. An interesting

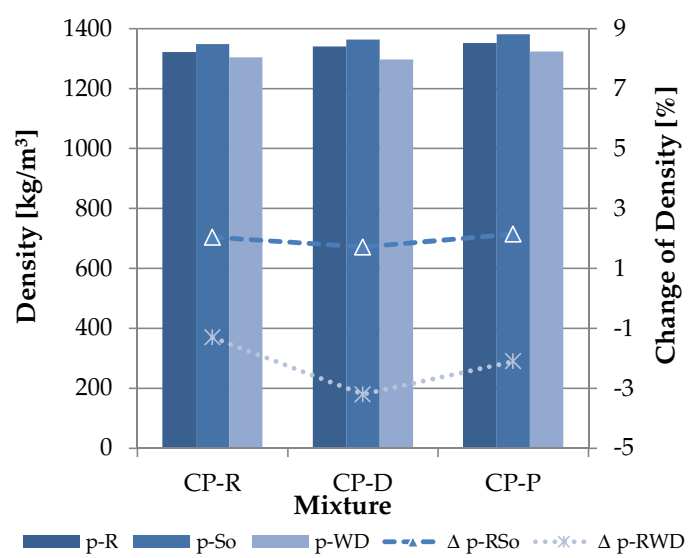

(a)

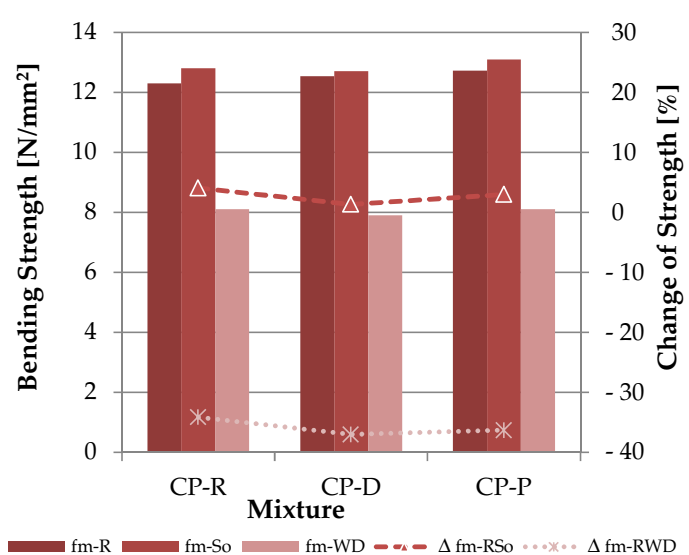

(b)

Fig. 12 Comparison of density (a) and bending strength (b) of the particleboards; bars-density (p) or bending strength (fm), curves - change in density $(\Delta \mathrm{p})$ or bending strength $(\Delta \mathrm{fm})$ 


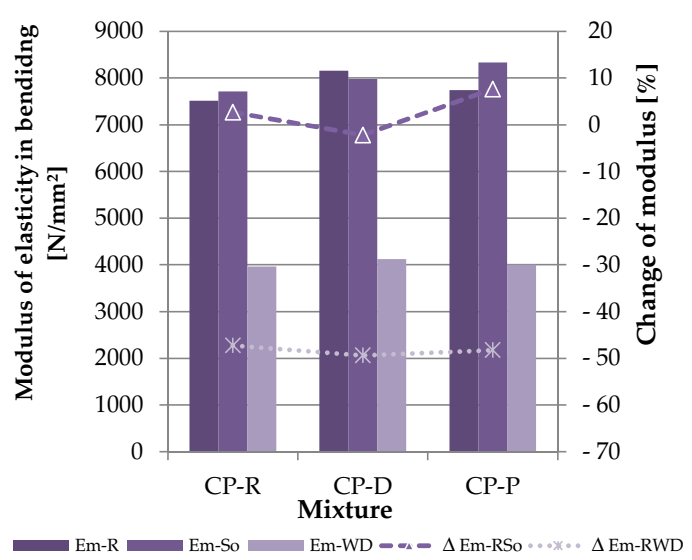

(a)

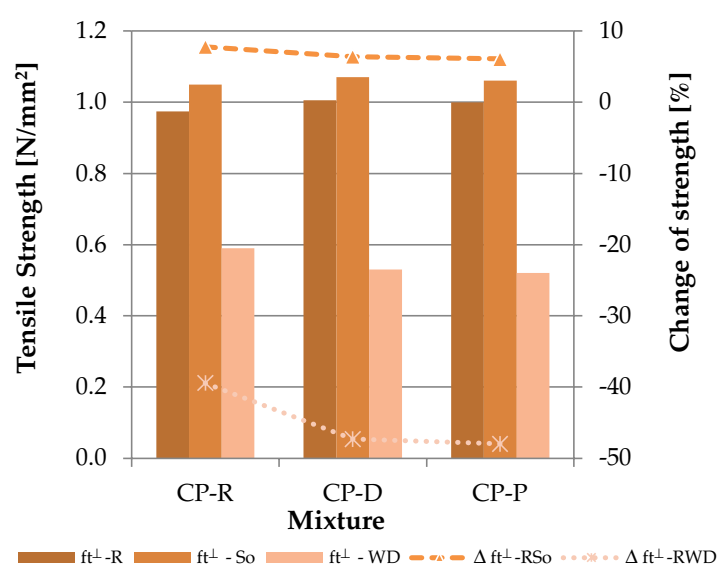

(b)

Fig. 13 Comparison of the modulus of elasticity in bending (a) and transverse tensile strength perpendicular to the plane of the board (b); barsmodulus of elasticity in bending $\left(E_{m}\right)$ or tensile strength ( $\left.\mathrm{ft}\right)$, curves - change in the modulus of elasticity $(\Delta \mathrm{Em})$ or tensile $\operatorname{strength}\left(\Delta \mathrm{f}_{\mathrm{t}}\right)$

finding is that the modified particleboard specimens showed higher strength than the reference. This is probably related to higher density of modified boards. It is obvious that the minor volume changes do not reduce the final bending strength. It is also evident that the modification by alternative components brings a slight benefit. In addition, the bending strength results prove that the sugars leached during immersion did not hinder the continuing hydration of the cement matrix. The boards subjected to the wet-dry cycling show significant decrease of bending strength, from 34 to $37 \%$, which confirms all aforementioned phenomena (release of residual stress in chips, de-bonding chips and cement matrix etc.).

Regarding the modulus of elasticity in bending (see Fig. 13a), the tested particleboards behave a little differently than in the case of bending strength. Immersed particleboards CP-D show a slight decrease in the bending modulus, specifically $2.2 \%$, while the other mixtures show an increase between 2.7 and $7.6 \%$. On the contrary, particleboards subjected to wet-dry cycles show decrease of modulus in range of 47.3 to $49.4 \%$. There is no strong relation of modulus to density trend.

Transverse tensile strength perpendicular to the plane of the board (see Fig. 13b) indicates the bond and coherence of the particleboards in the direction of their compacting, i.e. thickness. Strong decrease in tensile strength was determined after wet-dry cycling (39.4 to $48 \%$ ). Immersed boards show increased tensile strength. The smallest degree of swelling was found in CP-R, which also showed a slightly higher increase in tensile strength than modified boards CP-D and CP-P. This is a negative effect of swelling in thickness (release of stress and pressure of swelled chips on adjacent matrix). All phenomena (release of residual stress from pressing boards, orientation of chips, de-bonding chips and matrix, etc.) showed strong effect in lateral direction (thickness).

\section{Microstructure}

First, selected areas of the specimens were observed for 30 min (Figs. 14 and 15). During the examination, the specimens remained in the water bath. The structure of the particleboards was also analysed over the longer term; i.e. 1 through $504 \mathrm{~h}$, during which the specimens were removed from the water bath to be examined. Images of microstructure were taken immediately after the removal. The most interesting changes were observed after $0,1,24$, and $168 \mathrm{~h}$. It was possible to record movement of the chips in all three directions by 3D analysis (Figs. 16-18). Some publications examine the volume changes of wood as such. However, the wood that is part of a composite behaves differently. Specifically in cementbonded particleboards, the wood chips are surrounded by the cement matrix. Adjacent cement matrix prevents the wood from dilating normally. Moreover, the wood is chemically and thermally treated. Observing areas where cracks occurred in the wood/cement interfacial zone was interesting.

The examination by an optical microscope showed that the dynamics of volume (dimensional) changes is varying rapidly. Cracks situated in the interfacial zone close within several minutes. This is a result of the wood chips' swelling upon contact with water (Figs. 14 and 15). The initial width of chip (Fig. 14) was determined at $552 \mu \mathrm{m}$, after $3 \mathrm{~min} 609 \mu \mathrm{m}$ (10.3\% increase) and after $10 \mathrm{~min}$ $621 \mu \mathrm{m}$ (12.5\% increase). However, it must be emphasized that the adjacent crack allowed the spruce chip to 


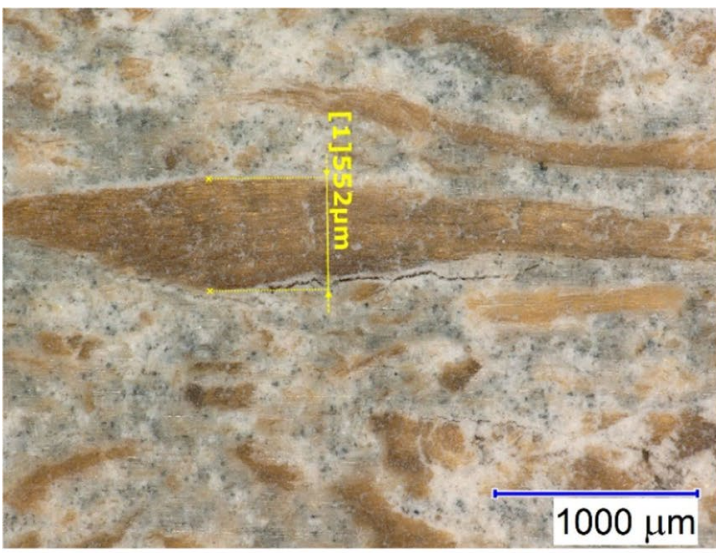

(a)

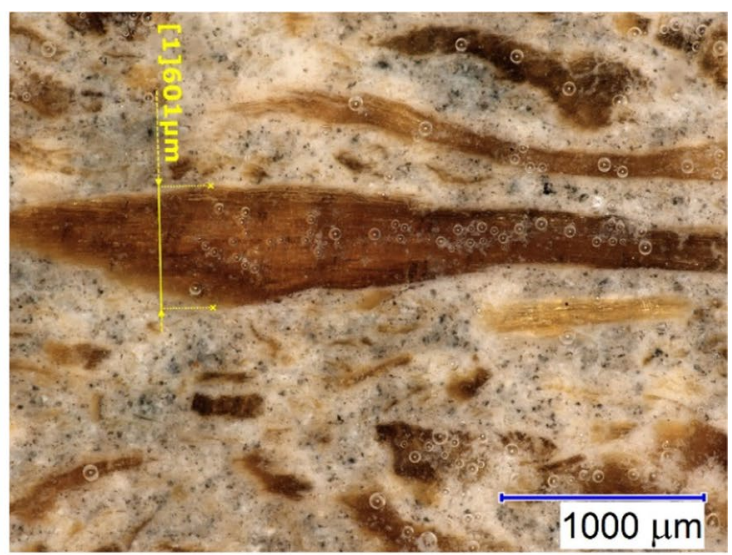

(b)

Fig. 14 Detailed structure of board CP-D—pictures from an optical microscope: a before immersion in water; $\mathbf{b}$ after 3 min of water saturation

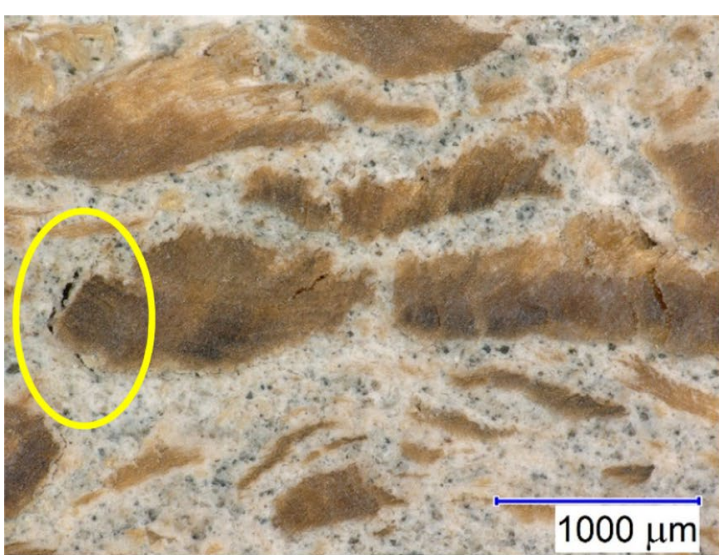

(a)

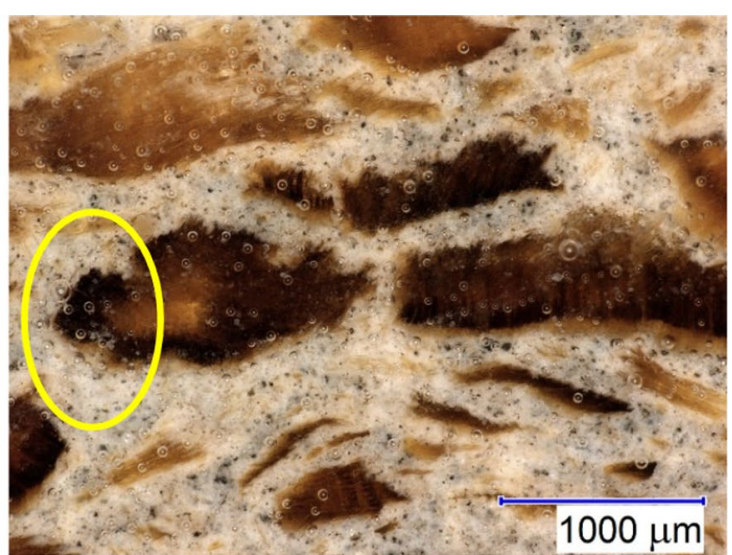

(b)

Fig. 15 Detailed structure of board CP-P_-pictures from an optical microscope: $\mathbf{a}$ before immersion in a water bath; $\mathbf{b}$ after 3 min of water saturation

move in this direction. The crack closes rather rapidly, already after $3 \mathrm{~min}$ (Fig. 14). Crack in the interfacial zone of CP-D board also closed immediately after $3 \mathrm{~min}$ of board immersion in water (Fig. 15). Reason is that cell walls are filled by water in the first stage. Saturation of cell walls by liquid water before reaching FSP is very fast. The dynamics of saturation is intensive up to $5 \mathrm{~min}$ from immersion to water bath. All free gaps, pores or cracks situated in contact zone of chips and matrix are closed due to spruce chips swelling in several minutes. Spruce wood is subjected to a macroscopic swelling, whereas, at the microscopic scale, the cell walls absorb bound water through the hemicellulose [56]. Water is bound to hemicellulose and amorphous component of cellulose. After reaching the FSP, there is no obvious macroscopic swelling. The cell walls are already saturated by bound water. The free water is located in lumens.

Swelling of spruce chips is obvious in all directions from microscopic pictures. Especially if there is free space around the chips. However, generally with regard to orientation of chips, swelling is more obvious in thickness direction (Fig. 9). There is an important factor when the boards are immersed to the water. That factor is releasing of stresses induced during the production of the particleboards.

Some chips are characterized by lower value of swelling. It could therefore mean that this particular spruce chip comes from the alternative component (particulate mixture). The wood contained in these components had been treated by a mineralization process. That is why 


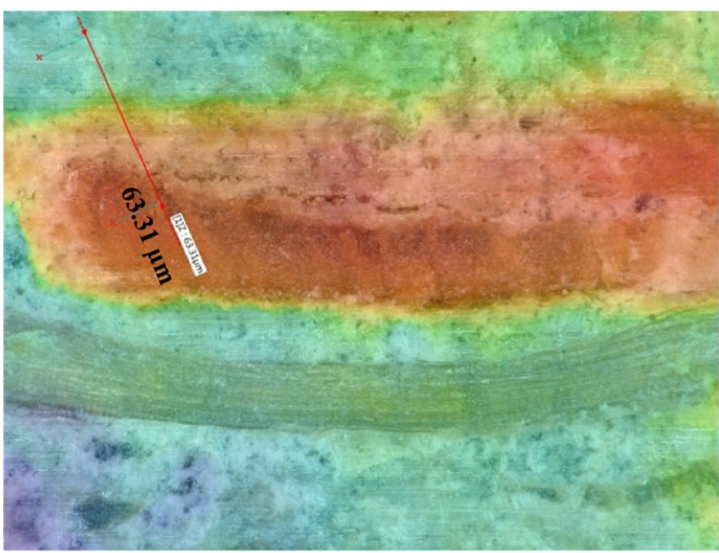

(a)

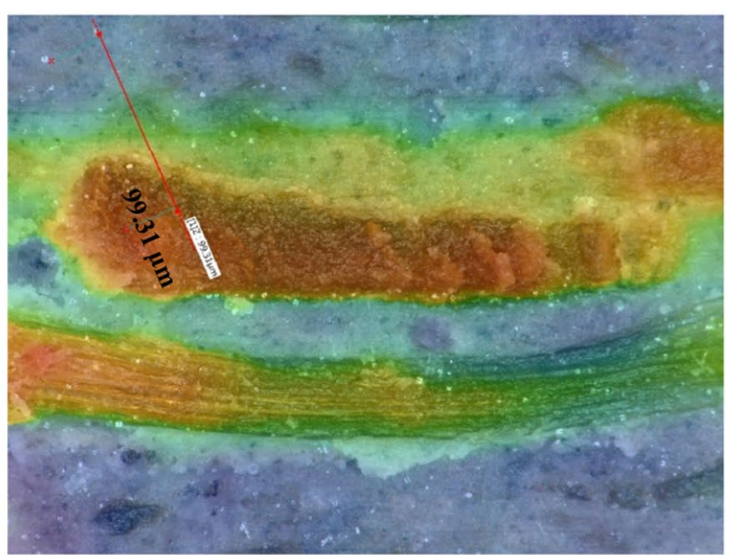

(b)

Fig. 16 Detailed structure of particleboard CP-P_-pictures from an optical microscope: a before immersion in water (height difference of $63.31 \mu \mathrm{m}$ ); b after $1 \mathrm{~h}$ of water saturation (height difference of $99.31 \mu \mathrm{m}$ )
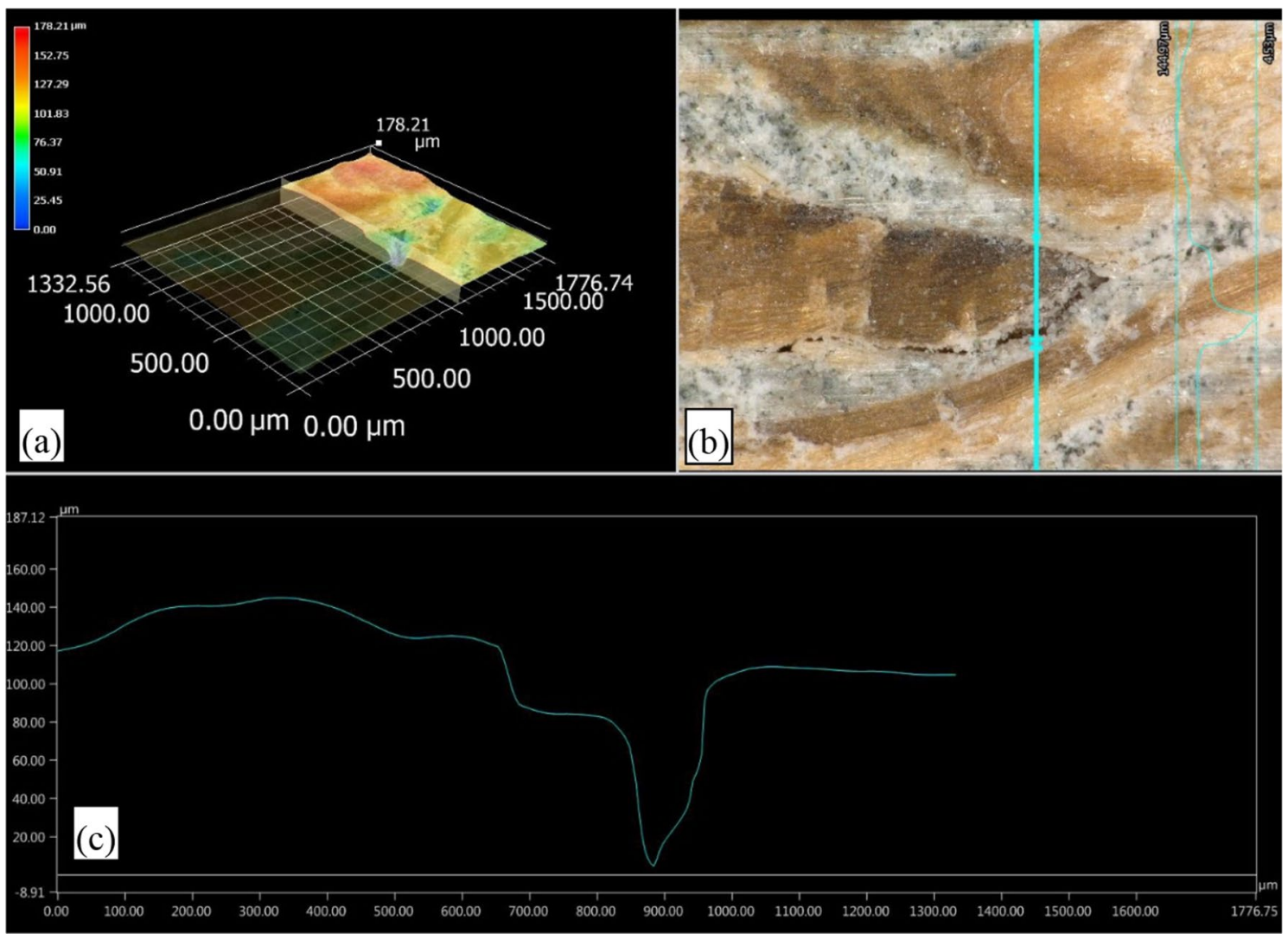

Fig. 17 Detailed picture of a crack in particleboard CP-D (before immersion in water)—picture from an optical microscope: a 3D view of the surface with a crack; $\mathbf{b} 2 \mathrm{D}$ view of the cross-section; $\mathbf{c}$ profile curve of the cross-section 

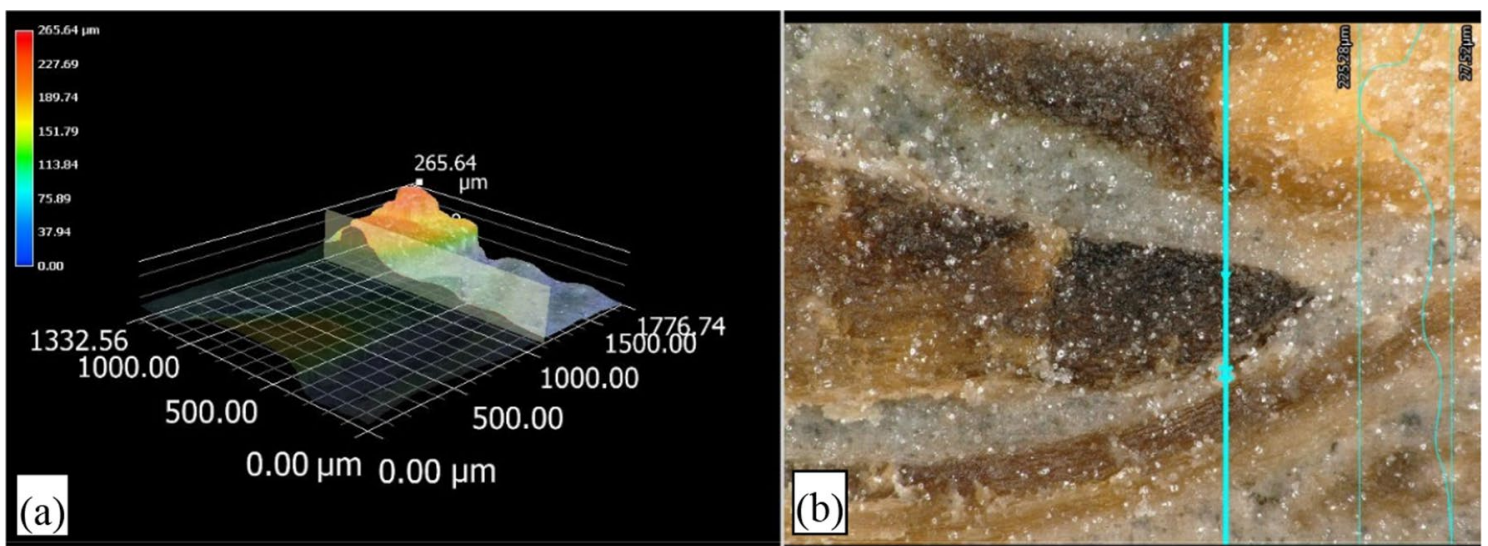

(a)

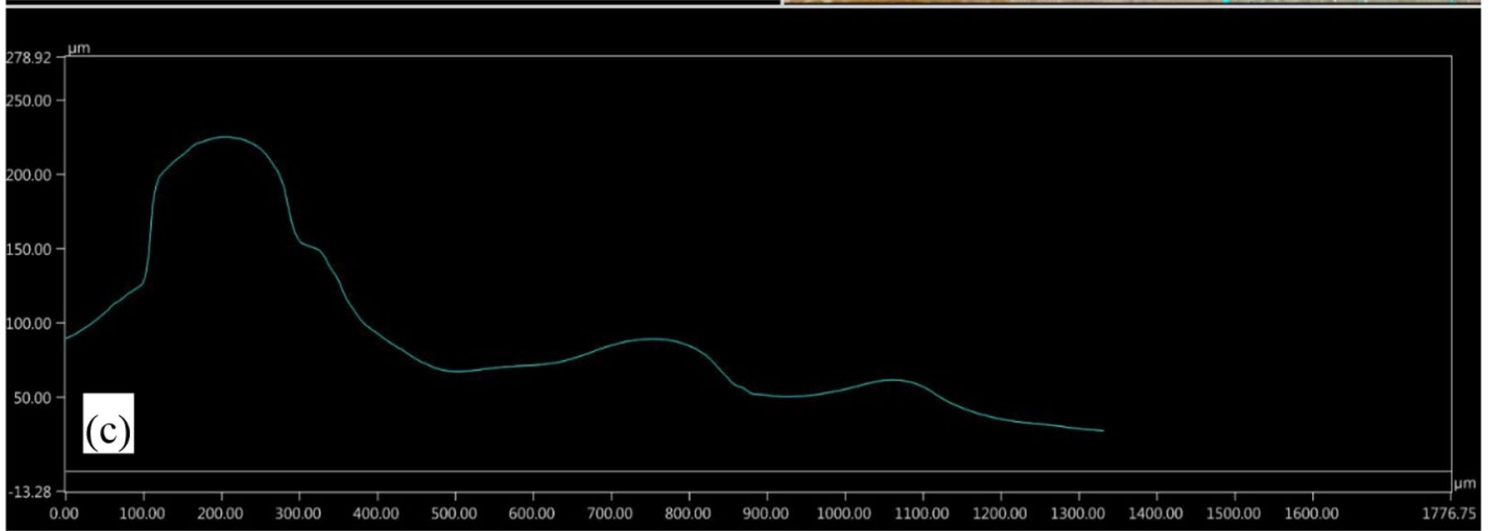

Fig. 18 Detailed picture of a crack in particleboard CP-D (after $1 \mathrm{~h}$ of immersion in water) - picture from an optical microscope: a 3D view the surface with the crack; $\mathbf{b} 2 \mathrm{D}$ view of the cross-section; c profile curve of the cross-section

these particles should be more resistant to swelling due to moisture.

Analysing the specimens' structural changes in $2 \mathrm{D}$ and 3D makes it possible to analyse the profile changes with more complexity. This analysing is interesting mainly in terms of the closure of cracks and volume changes. The following images show selected outcomes (see Figs. 17 and 18). The images show that the pictured crack closed within the first hour as the wood swelled.

It is evident that not all the spruce chips observed in the area undergo the same volume changes. This is caused either by their orientation, damage to their structure, or by their origin (whether they are primary spruce chips or part of the alternative components). However, a detailed microscopic analysis can be of great use in verifying, confirming, or explaining certain observations and findings obtained during the determination of dimensional changes in the cement-bonded particleboards. The combination of the $2 \mathrm{D}$ and $3 \mathrm{D}$ cross-section profile is particularly useful, as it enables an easy yet thorough analysis of these changes.

Irreversible extending of crack width was observed (Fig. 19) during wet-dry cycling. Also it is evident that chip itself was deteriorated, i.e. damaged structure is apparent. Failures formed mostly in ITZ zone between spruce chips and cement matrix. The reason is that different volume changes (within the chips and the matrix) during temperature and moisture fluctuation occurred. During wetting, the chips swelled and caused pressure on the adjacent matrix (supported by results and findings of Rowell [57]). This pressure could contribute to damage of surrounding cement matrix of the boards. Wood chips shrink more quickly than the matrix during drying phase. Therefore, separation of the chips and matrix occurs. Fluctuation in moisture and temperature caused decrease in mechanical properties of the particleboards (Figs. 12 and 13).

Apparent irreversible changes were determined in case of CP-P (Fig. 19), which is in accordance with previous results and findings (Fig. 10 and Table 4). Significant aspect is also structure of cement matrix, which is affected by the amount of substituent (particulate mixture $\mathrm{P}$ or dust $\mathrm{D}$ ). Increased amount of substituent $\mathrm{P}$ resulted in less compact and rigid structure. Less coherent structure of the boards is obvious from tensile strength results (Fig. 13b). Loss of coherence of the 


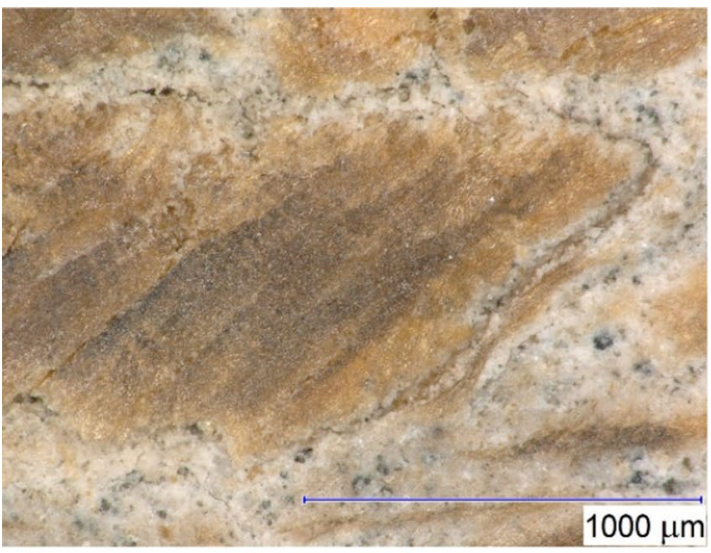

(a)

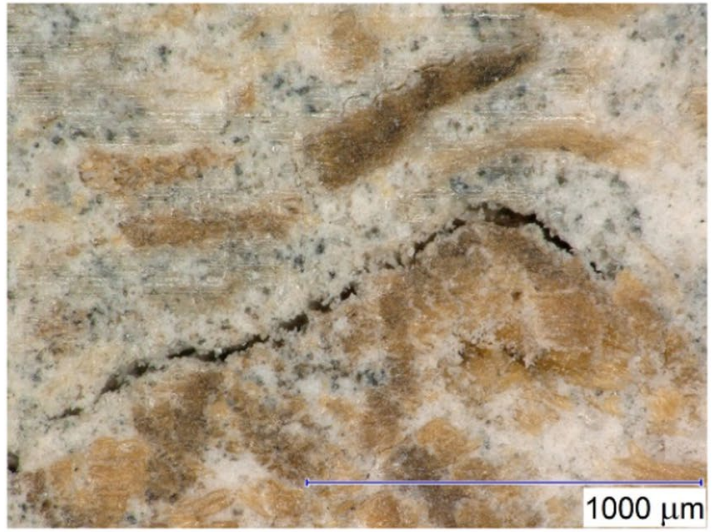

(c)

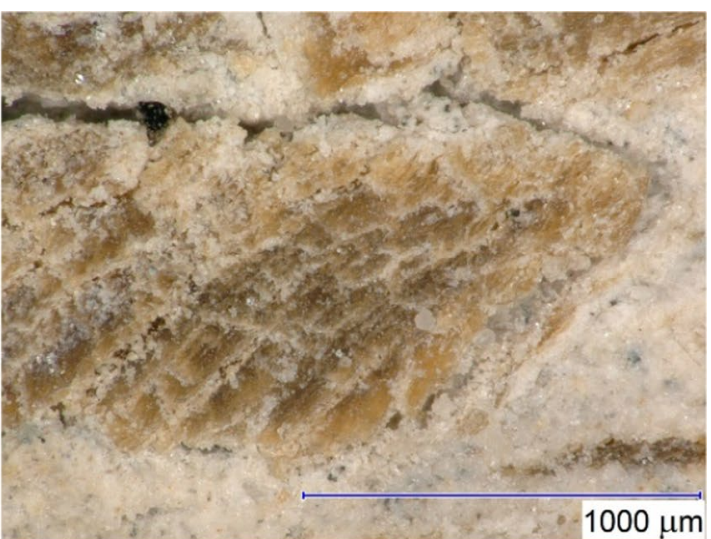

(b)

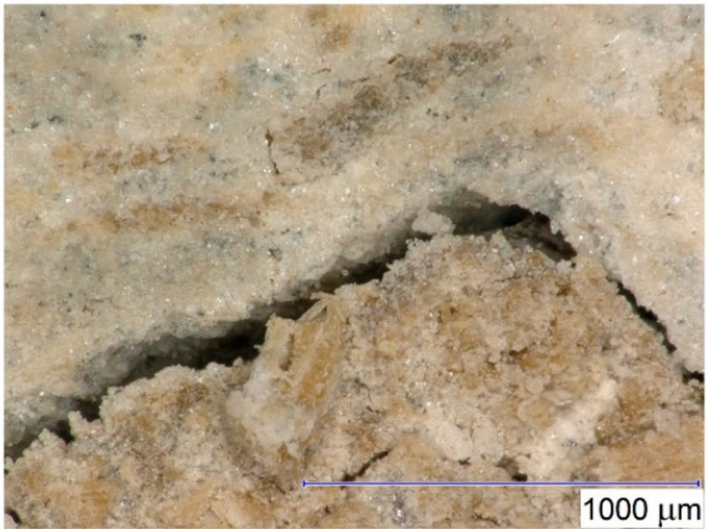

(d)

Fig. 19 Development of failure in contact zone of matrix and spruce chip within the particleboard during wet-dry cycling: $\mathbf{a}$ CP-R before cycling; $\mathbf{b}$ CP-R after 7 cycles; c CP-P before cycling; $\mathbf{d}$ CP-P after 7 cycles

tested boards was more apparent after wet-dry cycling. Irreversible changes of cement-bonded particleboards also relate to deformation of cement matrix. The matrix is subjected to irreversible changes during swelling and subsequent drying of the boards. Contrary, the chips are more flexible and reach almost the same dimensions after drying. Therefore, widened cracks in ITZ of analysed boards are apparent after 7 wet-dry cycles (Fig. 19b, d).

An interesting research would be also study of transport of the water in the boards and separate components (matrix and chips) in terms of different water entering the edge and inner structure of the boards. However, this research requires more complex and detailed study, which is above the scope of the presented study.

\section{Conclusions}

All the parameters were determined in terms of the effect of the particleboards' different composition.
Cement-bonded particleboards behave differently during water saturation (up to $504 \mathrm{~h}$ under water) depending on their composition. The changes in the observed parameters follow different dynamics. Particleboards with a modified composition are more susceptible to volume and dimensional changes. Most volume and dimensional changes occur roughly within the first $24 \mathrm{~h}$. Very fast changes were detected by optical microscopy within 3 to $5 \mathrm{~min}$ of being immersed in water. Between 24 and $96 \mathrm{~h}$ the rate at which pores and air voids close begins to decrease. Volume and mass changes occur at a different rate. Mass increases at larger increments than volume.

Mechanical properties (strength and modulus of elasticity) were not harmed by swelling. In fact, the $504 \mathrm{~h}$ of water saturation caused them to increase by a small degree. The continuing cement hydration had a stronger effect than the structural damage caused by the swelling of the wood within the particleboard matrix. On the other hand, boards subjected to wet-dry cycling deteriorated significantly. Especially, apparent decrease of 
strength (up to 50\%) and modulus has occurred. Microstructure also contained more failures and flaws.

Despite the fact that the properties of the wood chips had been stabilized as part of the manufacturing process, sugar leaching had occurred during the water saturation. A slightly higher sugar concentration was found only after $504 \mathrm{~h}$ of water saturation. However, the strength tests show that the leached sugars have not affected properties of the particleboards.

\begin{abstract}
Abbreviations
D: Dust produced by the cutting and grinding of the boards; P: Particulate mixture consisting of cement, wood chips, admixtures, etc.; CP-R: Reference cement-bonded particleboard; CP-D: Cement-bonded particleboards modified with D (7\%); CP-P: Cement-bonded particleboards modified with P (8\%); MSWI: Municipal solid waste incineration; W/C: Water/cement; TOC: Total organic carbon; $\mathrm{p}-\mathrm{R}$ : Density of reference boards; $\mathrm{p}$-So: Density of soaked boards; p-WD: Density of wet-dry cycled boards; $\triangle \mathrm{p}$-RSo: Difference between density of reference and soaked boards; $\triangle \mathrm{p}$-RWD: Difference between density of reference and wet-dry cycled boards; fm: Bending strength; Em: Modulus of elasticity in bending; $\mathrm{ft}$ : Transverse tensile strength perpendicular to the plane of the board.
\end{abstract}

\section{Acknowledgements}

All tests and analyses were carried out at Brno University of Technology, Faculty of Civil Engineering, Institute of Technology of Building Materials and Components, and at AdMaS Centre.

\section{Authors' contributions}

Conceptualization - TM, methodology - TM and LM, validation—JB, TM and $L M$, formal analysis - JB, investigation- TM, LM, ML and SV, resources—LM and $T M$, data curation - JB, writing — original draft preparation - $T M$, writing review and editing - TM and LM, visualization-TM and LM, supervision-TM and JB, project administration-TM, funding acquisition-TM and JB. All authors have read and approved the final manuscript.

\section{Funding}

Research presented in the article was funded by the Czech Science Foundation (GA ČR), project 19-00291S "Analysis of Processes during Forming the Structure in Silicate Composites with Organic Fillers and their Behaviour at Specific Conditions of Stress".

\section{Availability of data and materials}

The datasets used and/or analysed during the current study are available from the corresponding author on reasonable request.

\section{Declarations}

\section{Competing interests}

The authors declare no conflict of interest.

Received: 5 October 2021 Accepted: 17 December 2021

Published online: 29 December 2021

\section{References}

1. Odeyemi SO, Abdulwahab R, Adeniyi AG, Atoyebi OD (2020) Physical and mechanical properties of cement-bonded particle board produced from African balsam tree (Populous Balsamifera) and periwinkle shell residues. Results Eng 6:100-126

2. Wang L, Yu IKM, Tsang DCW, Yu K, Li S, Poon CS, Dai J-G (2018) Upcycling wood waste into fibre-reinforced magnesium phosphate cement particleboards. Constr Build Mater 159:54-63

3. Miranda de Lima AJ, Iwakiri S, Satyanarayana KG, Lomelí-Ramírez MG (2020) Preparation and characterization of wood-cement particleboards produced using metakaolin, calcined ceramics and residues of Pinus spp. J Build Eng 32:101722

4. Caprai V, Gauvin F, Schollbach K, Brouwers HJH (2019) MSWI bottom ash as binder replacement in wood cement composites. Constr Build Mater 196:672-680

5. Nadhari WNAW, Danish M, Nasir MSRM, Geng BJ (2019) Mechanical properties and dimensional stability of particleboard fabricated from steam pre-treated banana trunk waste particles. J Build Eng 26:100848

6. Papadopoulos AN (2008) Natural durability and performance of hornbeam cement bonded particleboard. Maderas Cienc Tecnol 10(2):93-98

7. Sotannde OA, Oluwadare AO, Ogedoh O, Adeogun PF (2012) Evaluation of cement-bonded particle board produced from Afzelia africana wood residues. J Eng Sci Technol 7(6):732-743

8. Fuwape JA, Oyagade AO (1993) Bending strength and dimensional stability of tropical wood-cement particleboard. Biores Technol 44(1):77-79

9. Borysiuk P, Jenczyk-Tolloczko I, Auriga R, Kordzikowski M (2019) Sugar beet pulp as raw material for particleboard production. Ind Crop Prod 141:111829

10. Taha I, Elkafafy MS, Mously HE (2018) Potential of utilizing tomato stalk as raw material for particleboards. Ain Shams Eng J 9(4):1457-1464

11. Amiandamhen SO, Izekor DN (2013) Effect of wood particle geometry and pre-treatments on the strength and sorption properties of cementbonded particle boards. J Appl Nat Sci 5(2):318-322

12. Hossain MU, Wang L, Yu IKM, Tsang DCW, Poon C-S (2018) Environmental and technical feasibility study of upcycling wood waste into cementbonded particleboard. Constr Build Mater 173:474-480

13. Wang L, Chen SS, Tsang DCW, Poon C-S, Shih K (2016) Value-added recycling of construction waste wood into noise and thermal insulating cement-bonded particleboards. Constr Build Mater 125:316-325

14. Wang L, Chen SS, Tsang DCW, Poon C-S, Shih K (2016) Recycling contaminated wood into eco-friendly particleboard using green cement and carbon dioxide curing. J Clean Prod 137:861-870

15. Cabral MR, Nakanishi EY, Mármol G, Palacios J, Godbout S, Lagacé R, Savastano H, Fiorelli I (2018) Potential of Jerusalem Artichoke (Helianthus tuberosus L.) stalks to produce cement-bonded particleboards. Ind Crop Prod 122:214-222

16. Karade SR (2010) Cement-bonded composites from lignocellulosic wastes. Constr Build Mater 24(8):1323-1330

17. Sassoni E, Manzi S, Motori A, Montecchi M, Canti M (2015) Experimental study on the physical-mechanical durability of innovative hemp-based composites for the building industry. Energy Build 104:316-322

18. Schwarzova I, Stevulova N, Melichar T (2017) Hemp fibre reinforced composites. In: Paper presented at "Environmental Engineering" 10th International Conference, Vilnius Gediminas Technical University, Lithuania, 27-28 April 2017

19. Schwarzova I, Stevulova N, Melichar T (2017) Lightweight composites based on technical hemp hurds in construction industry. Chem Eng Trans 57:1369-1374

20. Pelaez-Samaniego MR, Yadama V, Lowell E, Espinoza-Herrera R (2013) A review of wood thermal pretreatments to improve wood composite properties. Wood Sci Technol 47(6):1285-1319

21. Rowell RM (2005) Moisture properties. In: Rowell RM (ed) Handbook of wood chemistry and wood composites. CRC Press, Boca Raton

22. Christensen GN, Kelsey KE (1959) Die Sorption von Wasserdampf durch die chemischen Bestandteile des Holzes. Holz Roh Werkst 17:189-203

23. Janusa MA, Champagne CA, Fanguy JC, Heard GE, Laine PL, Landry AA (2000) Solidification/stabilization of lead with the aid of bagasse as an additive to Portland cement. Microchem J 65(3):255-259

24. Makarona E, Koutzagioti C, Salmas C, Ntalos G, Skoulikidou MC, Tsamis C (2017) Enhancing wood resistance to humidity with nanostructured ZnO coatings. Nano Struct Nano Objects 10:57-68

25. Ahmed SA, Morén T, Sehlstedt-Persson M, Blom Å (2017) Effect of oil impregnation on water repellency, dimensional stability and mold susceptibility of thermally modified European aspen and downy birch wood. J Wood Sci 63(1):74-82

26. Lee SH, Ashaari Z, Ang AF, Halip JA (2017) Dimensional stability of heat oil-cured particleboard made with oil palm trunk and rubberwood. Eur J Wood Wood Prod 75(2):285-288

27. Nasser RA, Salem MZM, Al-Mefarrej HA, Aref IM (2016) Use of tree pruning wastes for manufacturing of wood reinforced cement composites. Cement Concr Compos 72:246-256 
28. Li M, Nicolas V, Khelifa M, El Ganaoui M, Fierro V, Celzard A (2019) Modelling the hygrothermal behaviour of cement-bonded wood composite panels as permanent formwork. Ind Crop Prod 142:111784

29. Sulaiman O, Awalludin MF, Hashim R, Mondal MIH (2012) The effect of relative humidity on the physical and mechanical properties of oil palm trunk and rubberwood. Cellul Chem Technol 46(5-6):401-407

30. EN 633 (1996) Cement-bonded particleboards. Definition and classification, CEN

31. EN 634-1 (1997) Cement-bonded particleboards - specification - part 1: general requirements, CEN

32. EN 634-2 (2007) Cement-bonded particleboards - Specifications - Part 2: Requirements for OPC bonded particleboards for use in dry, humid and external conditions, CEN

33. EN 310 (1995) Wood based panels. Determination of modulus of elasticity in bending and of bending strength, CEN

34. EN 317 (1995) Particleboards and fibreboards; determination of swelling in thickness after immersion in water, CEN

35. EN 318 (2003) Wood-based panels - Determination of dimensional changes associated with changes in relative humidity, CEN

36. EN 319 (1994) Particleboards and fibreboards. Determination of transverse tensile strength perpendicular to the plane of the board, CEN

37. EN 323 (1994) Wood-based panels. Determination of density, CEN

38. EN 1328 (1998) Cement bonded particleboards - Determination of frost resistance, $C E N$

39. ASTM D 1037 (2012) Standard test methods for evaluating properties of wood-base fiber and particle panel materials1,ASTM International

40. Melichar T, Bydzovsky J (2019) Influence of dust waste containing a silicate matrix and organic filler on properties of cement composites [Vliv prachového odpadu s obsahem silikátové matrice a organického plniva na vlastnosti cementových kompozitů]. Waste Forum 4:378-390

41. Melichar T, Bydzovsky J, Dufka A (2019) Seldom used by-product from trimming cement-bonded particleboard shows potential for modifying building materials composition. Waste Forum 4:368-377

42. Melichar T, Venhodová E, Bydžovský J (2014) Analyzing of alternative raw materials for production of cement-bonded particle boards. Adv Mater Res 923:108-111

43. Fu Z, Zhou Y, Gao X, Liu H, Zhou F (2019) Changes of water related properties in radiata pine wood due to heat treatment. Constr Build Mater 227:116692

44. Fan MZ, Bonfield PW, Dinwoodie JM, Breese MC (1999) Dimensional instability of cement-bonded particleboard mechanisms of deformation of CBPB. Cem Concr Res 29:923-932

45. Fan MZ, Bonfield PW, Dinwoodie JM, Boxall J, Breese MC (2004) Dimensional instability of cement-bonded particleboard: the effect of surface coating. Cem Concr Res 34:1189-1197

46. CETRIS (2021) Basic properties of cement-bonded particleboards CETRIS ${ }^{\circledR}$ (Základní vlastnosti cementotřískových desek CETRIS $^{\circledR}$ ). Available via DIALOG. https://www.cetris.cz/pagedata_cz/download/671_2-zakladnivlastnosti.pdf?1527582590. Accessed 9 Nov 2021

47. Fuwape JA, Fabiyi JS, Osuntuyi EO (2007) Technical assessment of three layered cement-bonded boards produced from wastepaper and sawdust. Waste Manag 27(11):1611-1616

48. Okino EYA, de Souza MR, Santana MAE, da Alves MV, de Sousa ME, Teixeira DE (2004) Cement-bonded wood particleboard with a mixture of eucalypt and rubberwood. Cem Concr Compos 26(6):729-734

49. Zhou Y, Kamdem DP (2002) Effect of cement/wood ratio on the properties of cement-bonded particleboard using CCA-treated wood removed from service. For Prod J 52(3):77-81

50. Savastano H, Warden PG, Coutts RSP (2000) Brazilian waste fibres as reinforcement for cement-based composites. Cement Concr Compos 22(5):379-384

51. Rowell RM (2005) Chemical modification of wood. In: Rowell RM (ed) Handbook of wood chemistry and wood composites. CRC Press, Boca Raton, pp 381-420

52. Young JF (1972) A review of the mechanisms of set-retardation in Portland cement pastes containing organic admixtures. Cem Concr Res 2(4):415-433

53. Bentz DP, Coveney PV, Garboczi EJ, Kleyn MF, Stutzman PE (1994) Cellular automaton simulations of cement hydration and microstructure development. Modell Simul Mater Sci Eng 2(4):783
54. Fan MZ, Ndikontar MK, Zhou XM, Ngamveng JN (2012) Cement-bonded composites made from tropical woods: compatibility of wood and cement. Cement Concr Comp 36:135-140

55. Quiroga A, Marzocchi V, Rintoul I (2016) Influence of wood treatments on mechanical properties of wood-cement composites and of Populus Euroamericana wood fibers. Compos Part B Eng 84:25-32

56. Hachem ChE, Abahri K, Leclerc S, Bennacer R (2020) NMR and XRD quantification of bound and free water interaction of spruce wood fibers. Constr Build Mater 260:120470

57. Rowell RM (2004) Chemical modification, solid wood processing/chemical modification. In: Burley J, Evans J, Youngquist JA (eds) Encyclopedia of forest sciences. Elsevier Ltd, Oxford, pp 1269-1274

\section{Publisher's Note}

Springer Nature remains neutral with regard to jurisdictional claims in published maps and institutional affiliations.

\section{Submit your manuscript to a SpringerOpen ${ }^{\circ}$ journal and benefit from:}

- Convenient online submission

- Rigorous peer review

- Open access: articles freely available online

- High visibility within the field

- Retaining the copyright to your article

Submit your next manuscript at $\boldsymbol{\nabla}$ springeropen.com 